\title{
UNIVERSITY oflfork
}

This is a repository copy of The Red Sea, Coastal Landscapes, and Hominin Dispersals.

White Rose Research Online URL for this paper:

https://eprints.whiterose.ac.uk/10261/

\section{Book Section:}

Bailey, G. orcid.org/0000-0003-2656-830X (2009) The Red Sea, Coastal Landscapes, and Hominin Dispersals. In: Petraglia, M.D. and Rose, J.I., (eds.) The Evolution of Human Populations in Arabia. Vertebrate Palaeobiology and Palaeoanthropology . Springer , Dordrecht, Netherlands, pp. 15-37.

https://doi.org/10.1007/978-90-481-2719-1_2

\section{Reuse}

Items deposited in White Rose Research Online are protected by copyright, with all rights reserved unless indicated otherwise. They may be downloaded and/or printed for private study, or other acts as permitted by national copyright laws. The publisher or other rights holders may allow further reproduction and re-use of the full text version. This is indicated by the licence information on the White Rose Research Online record for the item.

\section{Takedown}

If you consider content in White Rose Research Online to be in breach of UK law, please notify us by emailing eprints@whiterose.ac.uk including the URL of the record and the reason for the withdrawal request. 


\title{
The Red Sea, Coastal Landscapes, and Hominin Dispersals ${ }^{1}$
}

\author{
Geoff Bailey
}

Keywords: Bab al Mandab, Coasts, Farasan Islands, Marine resources, Paleoenvironment, Paleoclimate, Red Sea

\section{Introduction}

The Red Sea has typically been viewed as a barrier to early human movement between Africa and Asia over the past five million years, and one that could be circumvented only through narrow exit points at either end, vulnerable to blockage by physical or climatic barriers (Figure 1). It is one of several significant obstacles cutting across 'savannahstan' (Dennell and Roebroeks, 2005), a broad swathe of herbivore-rich savannah and grassy plains that began to extend over a vast area stretching from West Africa to China with climatic cooling from at least 2.5 Mya, and a key macro-environmental context for early hominin dispersal ${ }^{1}$. However, this concept of the Red Sea Basin as a barrier should not obscure the fact that its coastal regions also hold considerable potential attractions for early human settlement, especially under climatic conditions wetter than today, including a complex tectonic and volcanic topography not unlike that of the African Rift, capable of providing localized fertility for plant and animal life, tactical opportunities for pursuit of herbivores and protection from predators (King and Bailey 2006), along with inshore and intertidal marine resources.

The modern climate of the region as a whole is generally arid or semi-arid, with spasmodic rainfall and limited supplies of surface water, and similar climates would have imposed a major limitation on past human settlement. However, there have clearly been periods of wetter climate in the past, and both marine and terrestrial environments have been subject to considerable change resulting from the climatic and sea level fluctuations of the glacial-interglacial cycle, as well as to longer-term factors of tectonic deformation associated with rifting, faulting and volcanic activity.

The Red Sea region therefore presents a rather complex valve controlling movement between Africa and Asia, with limited points of transit determined by physical and climatic barriers that are likely to have varied with long-term changes in paleogeography and climate. Although the possibility of direct human movement out of Africa across the Mediterranean has been raised, such routes would always have required sea crossings, even at the narrowest point of the Gibraltar Straits (ca. $11 \mathrm{~km}$ ), and there is currently no decisive evidence in favor of such movements (cf. Derricourt, 2005; O'Regan 2008) ${ }^{2}$. The Red Sea region remains the most obvious and most probably the only transit region for hominin

1

Geoff Bailey

Department of Archaeology

King's Manor

University of York

York, YO1 7EP

UK

emailgb502@york.ac.uk

Published version in M. Petraglia \& J. Rose (eds.). The Evolution of Human Populations in Arabia. Springer: Dordrecht, Netherlands, pp. 15-37. 2009. See http://www.springer.com 
movement between Africa and Eurasia throughout most of the Plio-Pleistocene. Therefore, an understanding of its long-term environmental history and potential for early human settlement is central to an understanding of the wider picture of hominin dispersal.

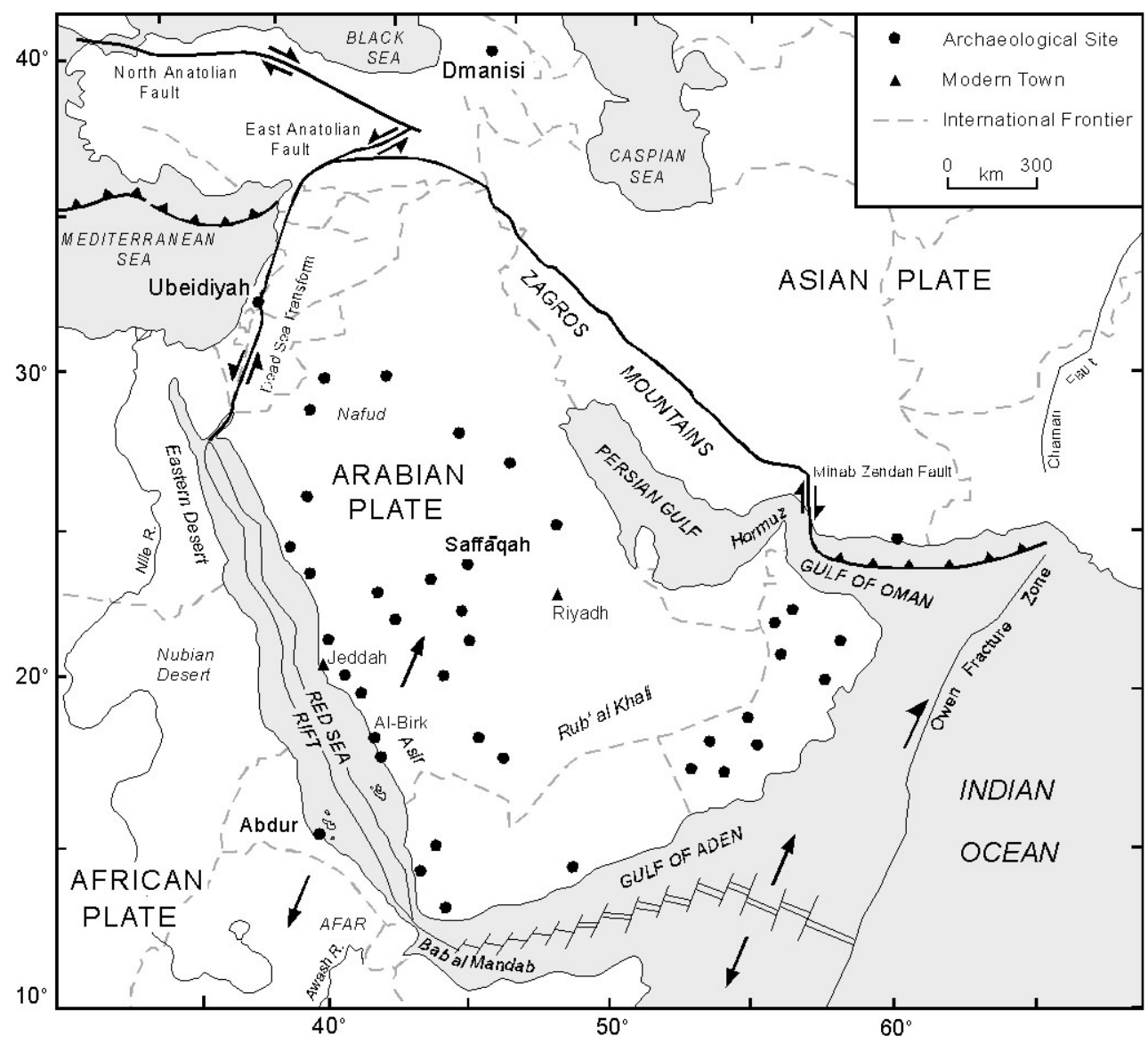

Figure 1. General map of the Red Sea and adjacent regions, showing plate boundaries and major faults. Arrows indicate direction of plate motions. Also shown is a simplified distribution of Lower and Middle Paleolithic archaeological sites in the Arabian Peninsula, together with sites elsewhere mentioned in the text. (C) C. Vita-Finzi and G. Bailey.

The case for an African origin of the Homo lineage and subsequent wider dispersal beyond Africa some time after about 1.8 Mya continues to command a wide consensus, so too the case for an African origin of anatomically modern Homo sapiens and their dispersal out of Africa some time after 150 kya. However, this does not rule out a priori the possibility that earlier hominin crossings took place at 2.5 Mya or even earlier, that earliest hominin populations originated over a wider zone that encompassed Africa, Arabia and Asia, or that movements between Africa and Asia may have been in both directions and not just one-way out of Africa (see Dennell and Roebroeks, 2005). Studies of PlioPleistocene mammalian fossils show that there has been two-way traffic between Asia and Africa, albeit intermittent (Tchernov 1992; Turner and O'Regan 2007), and some genetic studies of human ancestry also suggest a pattern of repeated contact implying two-way movement (Templeton 2002). Other mammals, of course, provide at best an imperfect analogy for human biogeography, not least because humans are omnivores who can feed on a wide range of resources including marine ones, and have some capacity for surmounting water barriers by swimming or rafting, both traits that could have extended far back into the earliest stages of human evolution. Whatever the outcome of these debates, the long-term 
history of the Red Sea Basin is likely to play an important role in their resolution, and the time span of investigation here is taken to be the past five million years, in order to encompass the widest range of possible scenarios for hominin dispersal. It is, however, inevitable that the most detailed reconstructions of environmental change and paleogeography are for the later stages of the Pleistocene, and that uncertainties and gaps in knowledge increase as one goes further back in time.

The aim of this chapter, then, is to examine critically the archeological and paleoenvironmental evidence pertaining to the Red Sea region both as a pathway of dispersal between Africa and Asia and as a zone of occupation in its own right that may have offered varied attractions for early human settlement regardless of the possibilities of onward dispersal to the north and the east - or to the south and west.

\section{Environmental and Archeological Context}

\section{Geographical Factors}

The Red Sea extends for $2000 \mathrm{~km}$ in a north-south direction through more than 17 degrees of latitude, from $12.5^{\circ} \mathrm{N}$ to $30^{\circ} \mathrm{N}$. Over most of its length it is very wide with an average width of $280 \mathrm{~km}$ and a maximum width of $354 \mathrm{~km}$, and an offshore topography that plunges quite steeply to reach a maximum depth along the central axis of $2850 \mathrm{~m}$ (Head, 1987a). It is therefore impassable without modern seafaring technology, even assuming lowered sea levels, except at the northern and southern extremities. In the north it divides into two branches on either side of the Sinai Peninsula, the relatively shallow $(50-70 \mathrm{~m})$ Gulf of Suez to the west, and the narrower and deeper (250-1800 m) Gulf of Aqaba to the east. In the south the basin is connected to the Indian Ocean by the Bab al-Mandab Straits, which is $29 \mathrm{~km}$ wide. The shallowest part of this southern channel is $-137 \mathrm{~m}$ at the Hanish Sill in the vicinity of the Hanish Islands, over $100 \mathrm{~km}$ to the north of the Straits (Figure 2). The geographical configuration of both northern and southern extremities is sensitive to changes of relative sea level linked to the glacial-interglacial cycle, and especially at the southern end, where the sea-channel is shallow enough that it might have been closed or easily crossed at low sea-level stands.

Under present day conditions there is only one means of circumventing the Red Sea on dry land and that is in the north across a neck of low-lying land about $120 \mathrm{~km}$ wide between the Mediterranean coastline and the Gulf of Suez, extending eastwards from the region of the Nile Delta to the Sinai Peninsula. This region would have become broader during periods of low sea level with the drying out of the Gulf of Suez, supplemented by a narrow extension of the Mediterranean coastal plain. There is no obvious physical barrier to human movement through this region. However, climatic conditions may have presented an obstacle during arid periods. Access from the vicinity of the Nile may also have been constrained by deep, steep-sided gorges during marine regressions as the Nile cut down to the lower sea level, as deep as $200 \mathrm{~m}$ during the Lower Pleistocene (Butzer, 1980), and by an extensive delta at high sea levels (cf. Tchernov, 1992). This northern route by no means offered a permanently open or easy pathway of dispersal. Moreover, the Nile appears to have had a much reduced flow of water intermittently during the Pleistocene, notably during the earlier part of the Pleistocene and during the last glacial maximum (Lamb et al., 2007). Nevertheless, by convention this northern route, whether via the Nile and the Mediterranean coast, or more directly between the Red Sea coast and the Jordan Valley via the Gulf of Suez and the shores of the Gulf of Aqaba, has been assumed to be the principal artery of contact between Africa and western Asia, an assumption reinforced by the abundant finds of Paleolithic archeology and African species of mammalian fauna in the Levant and early dates in the 1.8-1.4 Mya range at sites such as Ubeidiyah (Tchernov, 1992; Ron and Levi, 2001), and further north, in the Caucasus, at Dmanisi at 1.7 Mya (Lordkipanidze et al., 2000).

More recently, considerable attention has focused on the 'southern corridor' across the southern end of the Red Sea and around the coastlines of the Indian Ocean into the Indian subcontinent (Lahr \& Foley, 1994), reinforced by growing awareness of the substantial and widely distributed record of 
Paleolithic archeological sites in the Arabian Peninsula (Petraglia, 2003, 2007; Petraglia and Al-Sharekh, 2003; other chapters in this volume). The popularity of this route has been further strengthened by genetic studies based on comparisons of DNA characteristics in modern populations, which seem to suggest a single rapid dispersal of modern humans out of Africa at about 70,000 years ago (Oppenheimer, 2003; Forster and Matsumura, 2005; Macaulay et al., 2005; Thangaraj et al., 2005), an idea that has been coupled with a supposedly new emphasis on marine resources that attracted modern human populations to productive coastlines and propelled them eastwards around the rim of the Indian Ocean (Stringer, 2000; Walter et al., 2000; Mellars, 2006; Bulbeck, 2007). Similarities of early stone-tool industries between East Africa, Arabia and the Indian subcontinent have been discussed in relation to this hypothesis (e.g. Rose, 2004; Beyin, 2006; Mellars 2006), but the technological and typological characteristics of the industries in question are variable and sites and industries are patchily distributed over large territories (James and Petraglia, 2005; Petraglia, 2007). The balance of independent convergence versus cultural or demic diffusion in the interpretation of such widely separated material is difficult to establish with any confidence, and there is little as yet in this material that would argue decisively in favor of the southern route. At any rate, an interest in the southern corridor has stimulated closer investigation of the possibilities for transit of the southern end of the Red Sea under different climatic, topographic and sea level conditions (Bailey et al., 2007a).

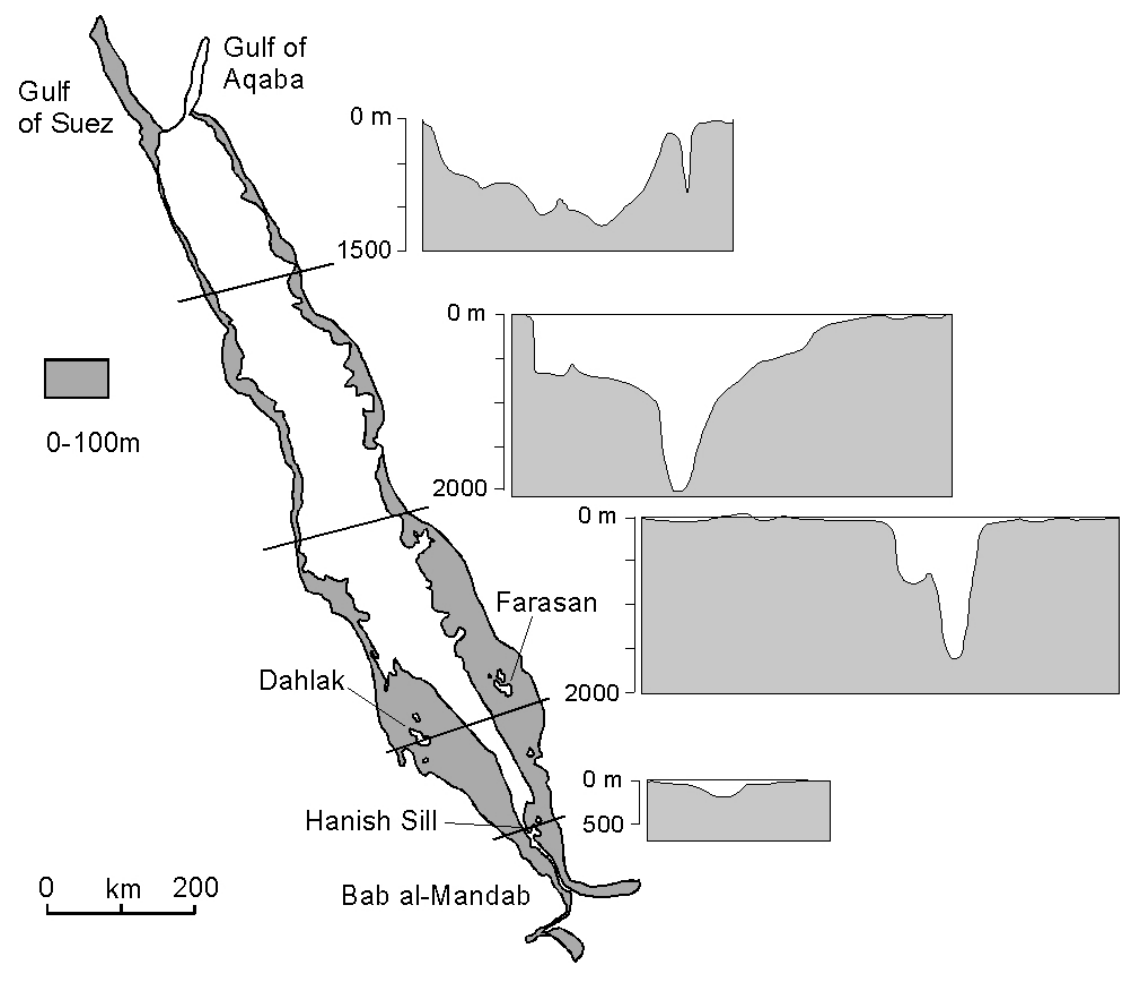

Figure 2. The Red Sea, showing features mentioned in the text and the amount of land exposed at the $-100 \mathrm{~m}$ bathymetric contour. Information from Head 1987. (c) G. Bailey.

Models of human dispersal based on deductions from the variability of DNA in present-day populations have exercised a particularly powerful influence on the scientific and popular imagination (cf. Oppenheimer, 2003; and other chapters in this volume). The evidence they provide of a single African source for all anatomically modern populations, broadly supported by the dating of human fossils, now commands a strong consensus, perhaps also the deduction of a single dispersal event out of Africa, while their combination with the notion of developing maritime adaptations and coastal dispersal represents a compelling synthesis. However, the capacity of DNA models to specify the date of this dispersal event is 
questionable, even more so their ability to discriminate between alternative pathways of dispersal between Africa and southern Asia. In this regard, such models provide, at best, hypotheses in need of further exploration and testing against independent sources of evidence, and raise as many questions as they purport to answer.

The concept of a maritime dispersal out of Africa, linked to the developing behavioral adaptations of modern humans, has proved especially attractive (cf. Walter et al., 2000; Mannino and Thomas, 2002; Oppenheimer, 2003; Bulbeck, 2007; Marean et al., 2007; Turner and O'Regan, 2007), but the evidence in its support is at best weak (Bailey et al. 2007a; Bailey in press), and raises a number of unresolved questions. Examination of potential routes between Northeast Africa and the Indian subcontinent (Field and Lahr 2005; Field et al. 2006) suggests that there are a number of significant barriers along the coastal corridor that would have required long diversions inland, although the question of what constitutes a barrier, especially under paleogeographic and environmental conditions unlike those of today, remains to be explored in more detail. Crossing the southern end of the Red Sea during periods of high sea level as at present would certainly require seaworthy boats, but less obviously so during periods of low sea level. The extension of the coastal landscape during periods of low sea level also would have altered the potential of many coastlines to act as zones of settlement and dispersal. The likelihood of short sea crossings across the Red Sea without the aid of boats, the potential of marine resources in this region, and evidence of their early exploitation are all matters in need of further investigation and are discussed later.

If human groups took the southern route across the Red Sea at $70 \mathrm{kya}$, when sea levels were relatively low, why should not earlier migrants have taken the same route during earlier periods of low sea level, as has long been hypothesized by others (e.g. Whalen et al., 1989; Whalen and Fritz, 2004)? Sea level, of course, is not the only factor. Climatic changes are also relevant, both as 'pull' and 'push' factors. Improved (wetter) climatic conditions might make both sides of the southern channel more attractive and fertile regions for plant and animal life and human settlement ('pull' factors). More arid conditions might have compelled populations to disperse more widely and to cross previously unpenetrated barriers in the search for new territory ('push' factors). Moreover, while it is true that the facility to cross the southern end of the Red Sea would have broadened the possibilities of contact and movement between Africa and Asia, such a dispersal route is not essential to populate Arabia or initiate movement thence further to the east. The whole of the Arabian Peninsula could have been filled with human and other mammalian species derived from Africa, or western Asia, via the northern end of the Red Sea, more or less instantaneously within the chronological resolution of existing dating techniques. Thus the nature of the environments, landscapes and resources around the Red Sea, and especially on the Arabian side, and their potential attractiveness to human settlement under different climatic regimes, may be as critical a question to pose as the possibility of transit across the southern end.

\section{Geology}

The Red Sea Basin originated as a terrestrial depression, perhaps as early as the Jurassic period over 150 Mya, with crustal thinning and depression accompanied by slow uplift of the surrounding flanks (Braithwaite, 1987). Later on, from about 40 Mya onwards in the late Oligocene, volcanic activity accompanied by occasional marine incursions from the Mediterranean became more marked, the main outlines of the Basin took shape, the Gulf of Aden began to open as a result of rifting that originated in the Indian Ocean, and rifting and seafloor spreading accentuated the separation of the Arabian Plate from Africa and turned the Red Sea into a progressively wider and deeper marine basin linked to the Indian Ocean (Bonatti, 1985; Omar and Steckler, 1995). The timing of some of these processes is not well dated. According to Girdler and Styles (1974), a first phase of sea-floor spreading occurred between 41 Mya and 34 Mya. During the Miocene, between about 25 Mya and 5 Mya, there was little further rifting, and high rates of evaporation in a semi-enclosed basin resulted in the formation of thick evaporites (salt deposits), suggesting conditions of considerable aridity. The evaporites are interleaved with marine deposits 
indicating intermittent incursion of the sea from the Mediterranean but rather unstable conditions for marine life. Opening of the Gulf of Aden had begun by 13 Mya (Manighetti et al., 1997; Hubert-Ferrari et al., 2003), and a second phase of sea-floor spreading within the Red Sea Basin took place after about 4-5 Mya (Girdler and Styles, 1974), accompanied by uplift in the area of Suez cutting off any further connection with the Mediterranean, and the establishment of a permanent marine connection to the Indian Ocean.

Rifting is the result of thinning and separation of the Earth's crust and is accompanied by volcanism and faulting, subsidence of the rift floor, and progressive uplift of the rift flanks to form mountain escarpments. During the second phase of seafloor spreading after 5 Mya, rifting created a deep axial trough in the center of the Basin (the Rift or Graben), which cut through earlier deposits. The uplifted escarpments are best developed on the Arabian side and towards the southern end, with highest elevations of over $3000 \mathrm{~m}$ in the Asir and Yemeni highlands in the Southwest corner of the Arabian Peninsula and in the Ethiopian highlands.

Bordering the mountain escarpments is a well-developed coastal plain, known on the Arabian side in its southern sector as the Tihama, which has an average width of about $60 \mathrm{~km}$. There is a similar feature on the Eritrean side, which widens out into the Afar Depression in the southwest corner. Further north, and especially in the Sudanese and Egyptian sectors, relief is less marked, the coastal plain narrower and the desert hinterland encroaches more closely on the coast.

Both sides of the Basin are composed of crystalline basement and sedimentary rocks, and these are capped locally by basalt flows, especially on the Arabian side, and in Ethiopia, where flood basalts are nearly $4000 \mathrm{~m}$ thick. Sand and gravel outwash deposits of Pleistocene or Holocene age cover much of the coastal plain, which is bordered by evaporites and coral reefs on the seaward side, and, in places, salt flats (sabkha) subject to periodic tidal inundation along the shore edge (Figure 3).

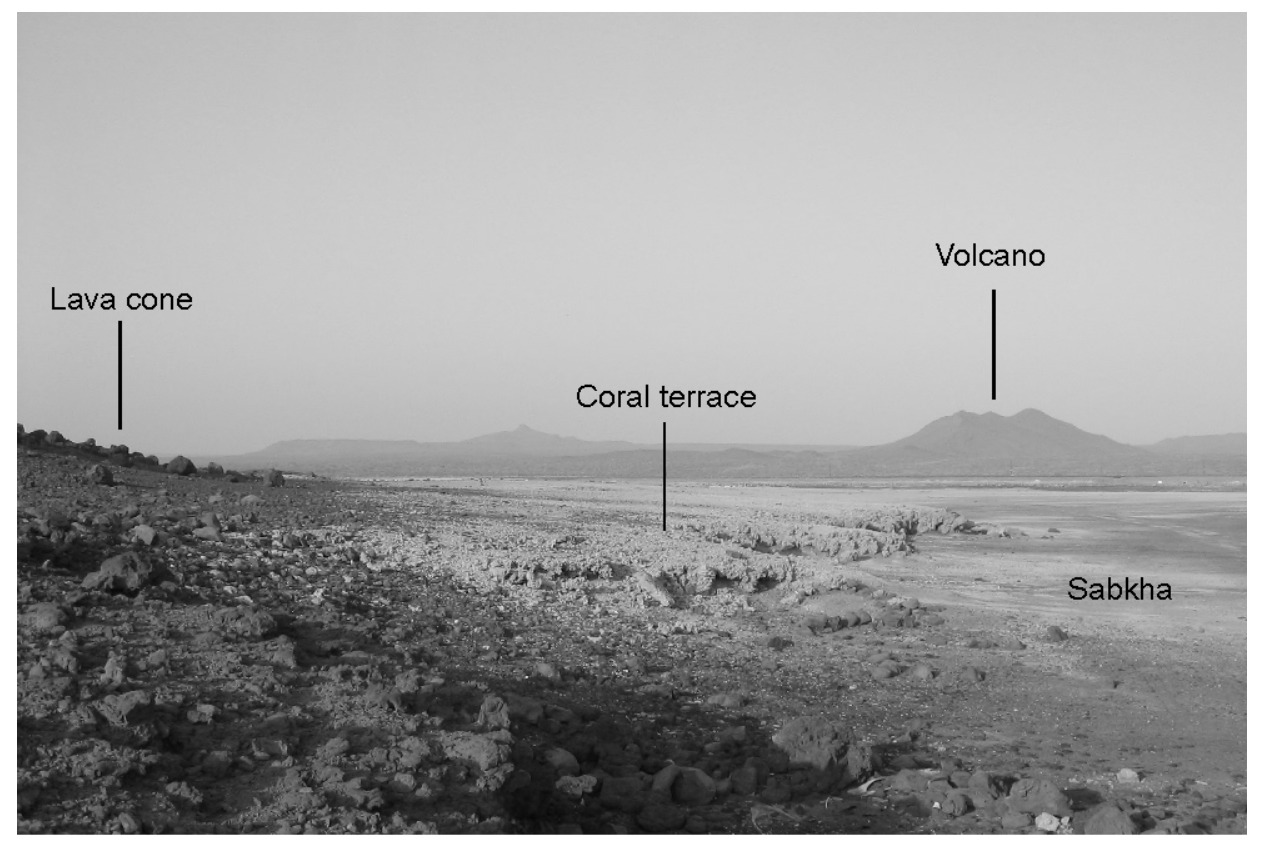

Figure 3. Geological features in the vicinity of the site of Al Birk on the coast of Saudi Arabia, looking north. Extinct volcanoes are visible on the far horizon. The lava cone on the left is dated at 1.3 Mya and the sea is to the left on the other side of the lava cone. Banked up against the lava cone is an elevated coral terrace believed to be of Last Interglacial data with Middle Stone Age artifacts on the surface. Photo G. Bailey, March 2004. 
The Miocene evaporites are often of great thickness and occur mostly at depth beneath younger deposits, but because of their low density and high mobility they tend to push upwards locally beneath overlying sediments to form salt domes or diapirs, resulting in local crustal distortion. These are sometimes accompanied by deep offshore depressions associated with salt withdrawal. These features are especially well marked in the region of the Farasan Islands, but are present elsewhere also (Bosence et al., 1998; Plaziat et al., 1998; Warren, 1999). Coral reefs are forming at the present day, and older cemented coral terraces are associated with previous high sea levels at higher elevations than the present day shoreline (Butzer and Hansen, 1968; Gvirtzman, 1994; Taviani, 1998).

Offshore topography is highly variable. In the Gulf of Aqaba, the offshore gradient dips almost vertically as a result of tectonic controls, and there are many other coastal sectors where the submerged continental shelf is quite narrow (Figure 2). Elsewhere, the seabed is shallower as in the Gulf of Suez, and in the southern sector of the Red Sea, where the most extensive areas of continental shelf would have been exposed during periods of low sea level, especially in the vicinity of the Farasan Islands and the Dahlak Archipelago.

The Red Sea Basin is thus a region of considerable geological instability, resulting from a combination of rifting and volcanism, more localized crustal movements caused by salt tectonics, and isostatic warping of coastal regions caused by the global effects of ice loading and alteration of water masses on the continental shelf with changes in sea level (Lambeck, 2004). All of these processes have important archeological implications, both for reconstructing the changing paleogeography of coastline configuration and possibilities of sea crossings, and for understanding the detailed character of the landscape and its relative resource-richness and attractiveness for human settlement in different areas and at different time periods.

\section{Climate and Environment}

Climatic conditions throughout the Red Sea coastal regions are semi-arid today and relatively uniform apart from temperature gradients associated with latitude (Edwards, 1987). In the north, maximum daily temperatures range from a low of $20^{\circ} \mathrm{C}$ in January to a high of $35^{\circ} \mathrm{C}$ in July, and in the south the corresponding range is $29^{\circ} \mathrm{C}$ to $40^{\circ} \mathrm{C}$. Rainfall rarely exceeds $180 \mathrm{~mm}$ per year and is mostly concentrated in the winter months, resulting in semi-desert vegetation that supports a sparse fauna of rodents, antelopes and gazelle, and patchy areas of greater fertility around permanent water sources and at higher altitude where rainfall is higher. Rainfall increases at higher elevation and especially in the high mountains of the south, which receive summer rains from the Indian Ocean monsoon system. In the Southwest corner of the Arabian Peninsula, in the highlands of Yemen and the Asir mountains of Saudi Arabia, annual rainfall ranges between about 300 and $1000 \mathrm{~mm}$. In the Ethiopian highlands, rainfall ranges between about $500 \mathrm{~mm}$ and over $2000 \mathrm{~mm}$, and nourishes permanent rivers such as the Blue Nile and the Awash, but these are far removed from the coastal regions of the Red Sea. The northern part of the Red Sea is influenced by Mediterranean cyclones, which bring winter rains, and this region is also sensitive to the effects of the North Atlantic oscillation, which leads to periods of greater or lesser aridity approximately every six years (Felis et al. 2000). The absence of perennial streams or rivers places a high premium on the availability of surface water in the form of springs, wells or oases, making the region as a whole sensitive to climatically-induced changes in precipitation resulting from shifts in the path of the main rain-bearing systems in the north and the southeast.

The assumption of prevailing aridity is one of the reasons why the Red Sea region and the Arabian Peninsula more widely has been discounted both as a zone of early human habitation and as a pathway of dispersal. However, there is little to choose in climatic terms between the north and south ends of the Red Sea, at least under present-day conditions. If climatic aridity was a deterrent to human settlement and dispersal in the south, it would seem to have been equally so in the north. There is no doubt that supplies of fresh water are a major limiting factor on human settlement under present-day climatic conditions, and that conditions have been periodically wetter in the past. But it is generally true to say that water supplies in the region as a whole are quite sensitive to climate change, and hence to 
fluctuations in the extent of territory available or suitable for human occupation, with expansion into the desert regions to east and west during periods of more favorable climate.

The marine environment of the Red Sea is one of the saltiest in the world because of high rates of evaporation and limited interchange with the Indian Ocean. In the Bab al-Mandab Straits salinity is close to the global ocean average of about 35\%, and then increases steadily on a south-north axis to reach a maximum of $40.5 \%$ in the north (Edwards, 1987). In winter, warmer and fresher water flows into the Red Sea near the surface from the Gulf of Aden, while cooler and saltier water flows outwards at depth. In summer the surface flow is reversed, and intermediate water from the Gulf of Aden flows into the Red Sea between the two outflowing layers (Siddall et al., 2002). Marine fertility and plankton production is highest in the south, as a result of the inflow of nutrients from the Indian Ocean and the extensive areas of submerged shelf that are shallow enough to facilitate recycling of nutrients from the seabed to the photosynthetic zone near the surface (Weikert, 1987). Fringing coral reefs and extensive beds of sea grass are also a significant source of nutrients for marine life in the form of plant detritus and organic matter. But in many areas nutrient productivity is low because of the deep water, the establishment of temperature and salinity gradients, and lack of disturbing currents, all of which inhibit recycling of nutrients, resulting in areas of marine 'desert'.

Coral reefs, sea grasses, and intermittent mangroves support a varied suite of reef fish and molluscs (Mastaller, 1987; Ormond and Edwards, 1987), and many inshore and intertidal organisms are adapted to conditions of high salinity (Jones et al., 1987). Marine food chains also support pelagic fish, turtles and sea mammals such as dugong, whales and dolphins (Frazier et al. 1987). The marine fauna is of Indo-Pacific origin (apart from a small number of species that have migrated recently from the Mediterranean through the Suez Canal). Organisms that inhabit the intertidal and shallow sublittoral zones are generally impoverished in numbers of species compared to the Indian Ocean because of extreme conditions of high temperature and salinity, and these conditions would have become more extreme during periods of low sea level, resulting in a degree of endemism, with species that are adapted to much higher salinities and temperatures than their Indian Ocean equivalents (Jones et al., 1987). The most abundant fisheries are in the south in the vicinity of the Farasan and Dahlak islands, though these do not apparently compare in potential abundance with the richer fisheries of the Persian Gulf (Head, 1987b; Ormond and Edwards, 1987).

As on land, marine productivity is likely to have been sensitive to climatically induced changes, especially the increased rates of evaporation and higher salinity associated with a drop in sea level and reduced inflow from the Indian Ocean.

\section{Archeological Context}

The Afar region in the southwest corner of the broader region under discussion here offers one of the longest sequences and some of the earliest hominin fossils in Africa, including finds of Australopithecus afarensis and Ardipithecus ramidus, and earliest fossil remains of modern humans (Johansen and Taieb, 1976; Woldegabriel et al., 1994; White et al., 2003). Whether this reflects unusually favorable geological conditions for exposing early deposits compared to other regions or a genuine focus of early hominin evolution and settlement remains unclear. But, as the northernmost sector of the African Rift, it shares many of the dynamic landscape features associated more generally with the Rift and its attractiveness to early hominin settlement, including complex topography, mosaic environments, diverse resources, and abundant supplies of surface water. It is also an obvious bridgehead for movement into the coastal regions of the Red Sea. Substantial finds of material have also, of course, been recorded in the Nile Valley and the adjacent desert regions, notably the Fayum (Wendorf and Marks, 1968; Wendorf, 1976; Vermeersch, 2001), though early Pleistocene or earlier material is elusive, perhaps because of lack of suitably early geological exposures.

On the African side of the Red Sea in coastal regions proper, sites are more patchily distributed, reflecting amongst other factors the vagaries of exploration and geological visibility. Acheulean and 
Middle Stone Age material has been recovered, often in association with elevated coral terraces formed at previous periods of high sea level, notably in the north (Plaziat et al., 1998), in Djibouti (Faure and Roubet, 1968), and in Eritrea, where there is an important concentration of sites (Beyin and Shea, 2007) including the important find of Abdur dated at ca. $130 \mathrm{kya}$ and associated with faunal remains and claims for the exploitation of marine resources (Walter et al., 2000). Sondheim in the hinterland of the Egyptian coastal sector represents a rare cave site with a late Pleistocene archeological sequence (Van Peer, 1998).

Similar material has been found on the Arabian side. Although the Arabian Peninsula has often been discounted as an arid and inaccessible cul-de-sac cut off by the Red Sea, there are large numbers of Paleolithic sites widely distributed across the region, mostly discovered during a series of surveys organized in the 1970s and 1980s by the Comprehensive Archaeological Survey Program of Saudi Arabia (for the Red Sea zone and Arabian escarpment, see in particular Zarins et al., 1979, 1980, 1981, 1982; Killick et al., 1981; Ingraham et al. 1981; Gilmore et al., 1982; also Caton-Thompson 1953), with additional surveys and excavation by Norman Whalen (Whalen et al., 1983, 1984, 1986, 1988), and by early expeditions in the Yemen (Amirkanov, 1991), added to by more recent explorations (see Petraglia, 2003, 2007; Rose, 2004; chapters in this volume). These include Acheulean and Middle Stone Age sites associated with coral terraces on the Red Sea shoreline showing general similarities with the material on the African side of the Red Sea. Sites are also widely distributed in other landscape settings, including coastal settings in the broad sense, that is sites on or close to the present-day shoreline and in the coastal hinterland, the mountain escarpment, and inland basins associated with paleo-lakes, springs and drainage channels, many of which are dry under present-day climatic conditions (Petraglia, 2003, 2007; Petraglia and Alsharekh, 2003; other chapters in this volume). There are particularly important concentrations of sites on the Red Sea side of the Arabian escarpment in the region of Jeddah, the southern coastal sector between Al Birk and Jizan, the Asir Highlands, and the wadis draining to the east (Figure 1).

Most of these sites are surface sites, and dates are for the most part lacking. Some material has been described as Oldowan, but whether this material is genuinely as early as that label suggests, or simply the result of poor quality local raw material, expedient tool use, or incomplete sampling remains unclear in the absence of any geological or radiometric dates. Uranium series dating of calcite concretions on artifacts from Saffāqah, near Dawadmi, indicates a minimum age of ca. 100 kya or ca. 200 kya (Whalen et al., 1984). At Al Birk, on the coast, the maximum age for the material is 1.3 Mya (the date of the lava cone which provided the raw materials for artifact manufacture in the vicinity, Bailey et al. 2007a,b), while other material at that site and elsewhere along the Red Sea coastline is associated with an elevated coral terrace of presumed Last Interglacial age (Bailey et al., 2007a).

\section{Paleoenvironment and Resources}

\section{Sea-level Change and the Southern Pathway}

The general pattern of eustatic sea-level change over the last glacial-interglacial cycle according to a variety of sources of information is shown in Figure 4. The different sea level curves are derived from different sources of information, subject to varying margins of uncertainty, and show differences of detail but broad agreement in general trends and a maximum amplitude between interglacial and glacialmaximum sea levels of about 115-130 m. The $100 \mathrm{~m}$ bathymetric contour in the Red Sea provides a useful approximation of coastline configuration at the glacial maximum, and highlights the extensive areas of new land exposed in the southern basin and the narrowness of the channel over the Hanish Sill and through the Bab al-Mandab Straits (Figure 2).

A more detailed analysis of changing coastline configuration in the southern channel at different sea level positions and dates is shown in Figure 5, based on bathymetric data and modeling of isostatic distortion (Bailey et al., 2007a, in prep). Margins of error in this method of reconstruction make it impossible to be certain whether or not there was a land connection at extreme low sea level, but any such 
connection would have been only a few meters in elevation and unlikely to have formed an effective barrier to the movement of sea water between the Red Sea and the Gulf of Aden. Interpretations of the Red Sea deep-sea isotope record confirm the absence of an enduring barrier at any time during the past 400,000 years, based on the absence of extreme isotope values that would be expected had the Basin become cut off from the Indian Ocean and subjected to very high salinity (Siddall et al., 2003). Fernandes et al. (2006) claim that the sea channel would never have been less than about $4 \mathrm{~km}$ wide and $15 \mathrm{~m}$ deep. However, the deduction of channel geometry from the isotope record is subject to its own margins of uncertainty, and while the evidence suggests uninterrupted flow of water between the Red Sea and the Gulf of Aden even at the lowest sea level, the detailed modeling of coastline configuration shown in simplified form in Figure 5d suggests that the channel might equally well have comprised a series of narrow braided channels of varying depth rather than a single broad one.

How far we should regard such a crossing as a barrier or a disincentive to human movement across the Straits is a matter of opinion and depends on assumptions about the ability of the populations in question to make rafts or boats, or to swim across several kilometers of water, and the attractions of resources on the other side of the channel. Certainly the data suggest that it would not have been possible to make the crossing without getting wet, even at lowest sea level. However, we might argue that it would have been relatively simple to make short crossings by simple rafting or by swimming, aided by warm sea temperatures and the increased buoyancy resulting from higher salinities. Current flow in the narrowed channel was probably higher than today, but estimates of likely flow rates suggest that this is unlikely to have been a significant hazard (Bailey et al., 2007a).

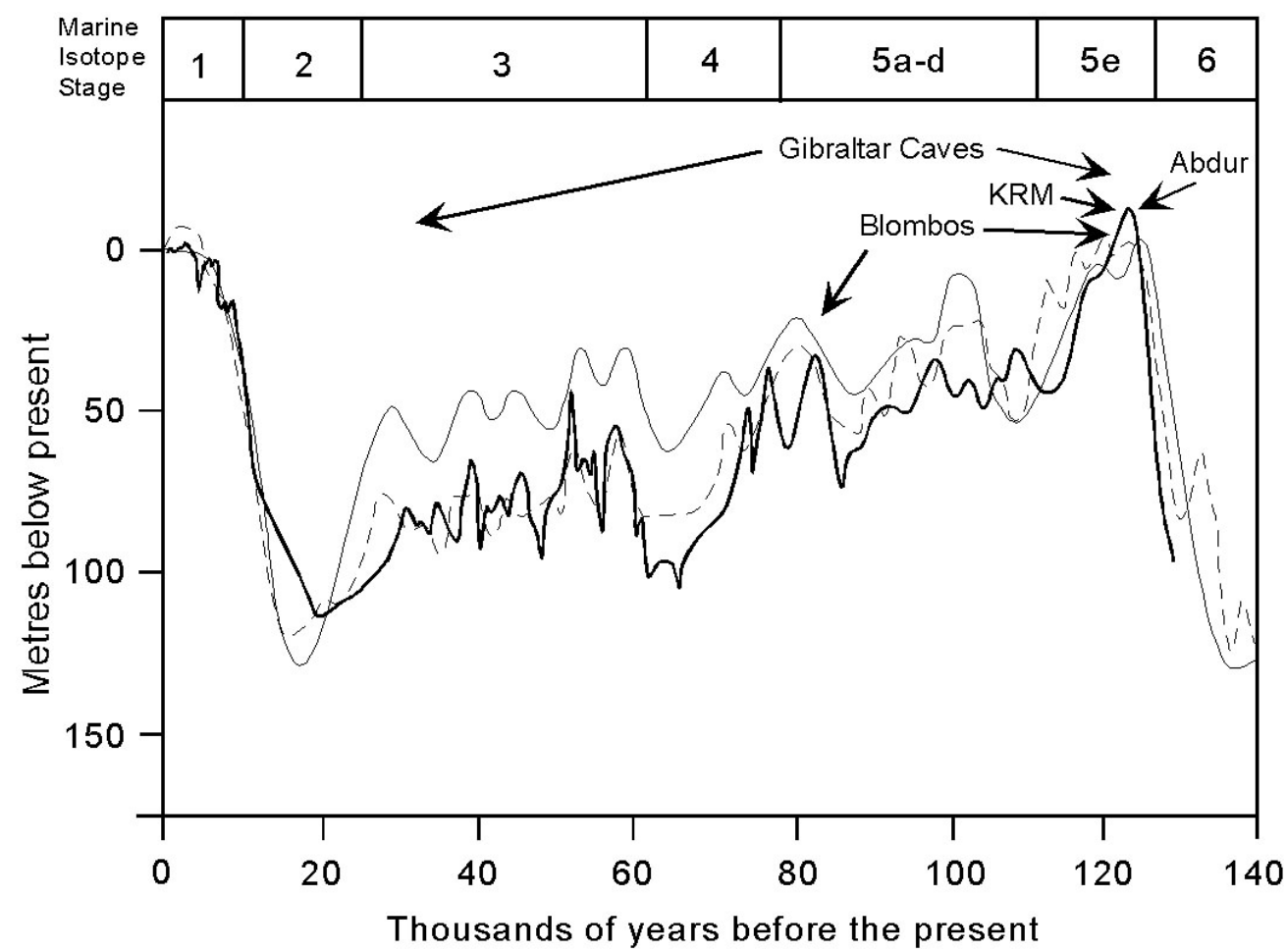

Figure 4. Global sea-level change over the past 140,000 years. The dashed grey line is based on deep-sea oceanic isotope records of planktonic and benthic fauna, the solid gray line shows the same curve corrected for temperature effects using dated and elevated marine terraces in New Guinea, the dark solid line is based on isotope records from the Red Sea. Coastal archaeological sites dated to MIS 5 with marine indicators are also shown (KRM is Klasies River Mouth). Sea level data are based on Chappell and Shackleton 1986, Lambeck and Chappell 2001, Shackleton 1987, Van Andel 1989, Siddall et al. 2003. (C) G. Bailey. 
Whether the crossing could have been made at intermediate sea levels without simple rafts or boats is less certain. At a relative sea-level depth of about $-50 \mathrm{~m}$. equivalent to the 12 kya reconstruction of Figure 5a, island hopping via the enlarged islands of Hanish al-Kabir and Az-Zuqur would have required five sea crossings, two involving distances of at least $10 \mathrm{~km}$, which would arguably have been marginal without effective rafts or boats. At a relative sea-level depth of about $-70 \mathrm{~m}$, equivalent to the 14 kya reconstruction of Figure 5b, two sea crossings of ca. $10 \mathrm{~km}$ would have been required, which still looks marginal without some form of water transport. At a relative sea-level depth of about -90 to -100 $\mathrm{m}$, equivalent to the 16 kya reconstruction of Figure $5 \mathrm{c}$, a single crossing of, at most, $5 \mathrm{~km}$ would have been required. Taking a conservative view of the likelihood of sea crossings by drifting, floating or active swimming, we might suggest a high probability of crossings at relative sea level depths greater than -100 $\mathrm{m}$. With simple rafts or boats the window of opportunity might widen to periods when sea level was at least $-50 \mathrm{~m}$ or deeper.
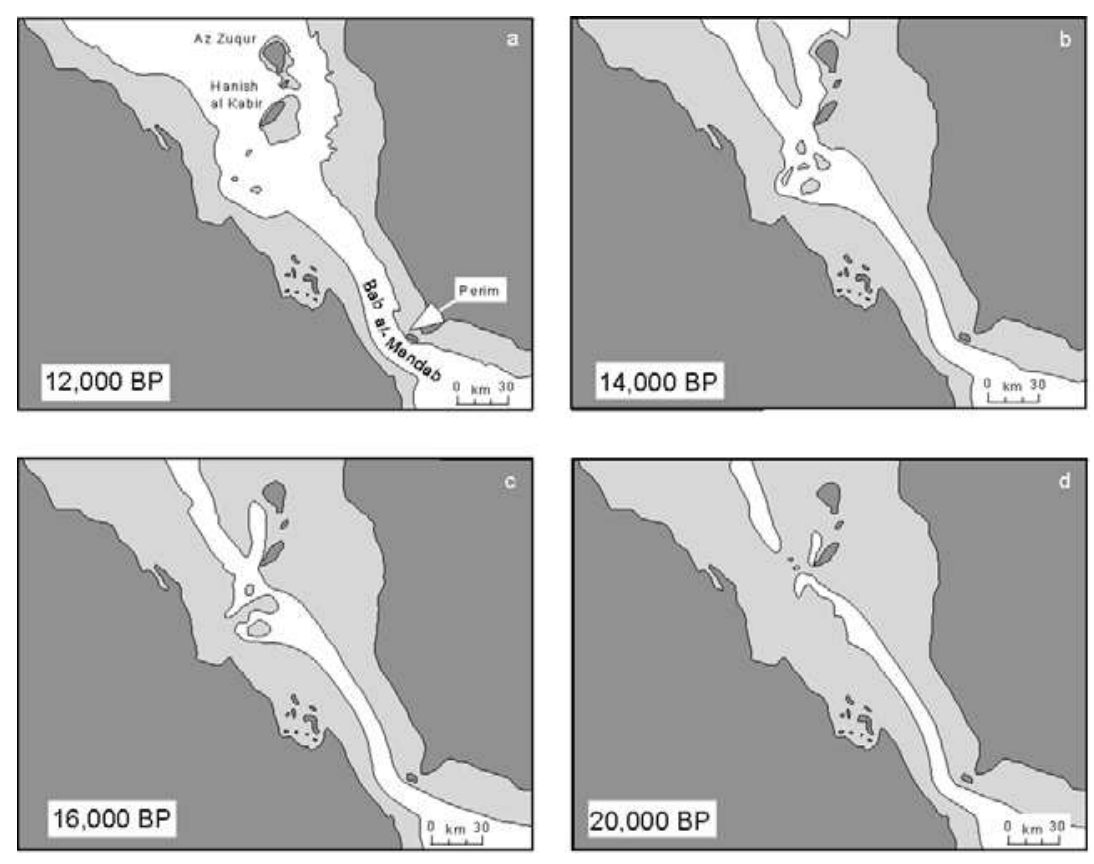

Figure 5. Shoreline positions in the region of the Bab al-Mandab Straits and the Hanish Islands at different periods of the last glacial cycle, taking account of isostatic modeling of crustal deformation. Dark gray is land at modern sea level. Light gray is land exposed when sea level was lower. The 20,000 BP figure shows the position of the coastline at the maximum marine regression of $-120 \mathrm{~m}$ at the last glacial maximum, approximate relative sea level positions for the other figures are $-90 \mathrm{~m}$ at $16,000 \mathrm{BP},-70 \mathrm{~m}$ at $14,000 \mathrm{BP}$ and $-50 \mathrm{~m}$ at $12,000 \mathrm{BP}$. Dates are calibrated radiocarbon years. Figure (d) suggests closure of the Red Sea at 20,000 BP, but this is not certain, given margins of error in the mapping technique, and the land bridge in any case would have been so low lying that it is unlikely to have formed a permanent barrier to exchange of seawater. See text for further discussion. Data compiled by Kurt Lambeck. (C) G. Bailey.

The periods when sea crossings might have taken place, using the above criteria, are shown in Figure 6 . The windows of opportunity are clearly only very approximate, both because of the assumptions involved, and because different sea level curves give different results, the local curve derived from the Red Sea giving the longest periods of potential crossing. On this basis, crossings at sea levels below $-100 \mathrm{~m}$ could have occurred over a period of 5000 to 8000 years at the glacial maximum (Table 1). At $-50 \mathrm{~m}$ the divergence between different sea-level curves is greater, with the possibility of crossings over a 
period that ranges from 19,000 to 70,000 years. Of course, with seaworthy boats crossings might have occurred even at high sea levels. Such a possibility is naturally raised by the much longer sea journeys undertaken by the earliest immigrants to Australia and New Guinea as much as 50,000 years ago. In that region, however, such an achievement was made possible not only by favorable winds and currents, but also by large quantities of bamboo washed down to the coast and out to sea during the monsoon season, providing a ready supply of floatable material that could easily be lashed together to provide serviceable water craft. Such circumstances probably do not apply to the Red Sea region. In any case, any form of crossing would have been easier when sea levels were lower and the channel was narrower.

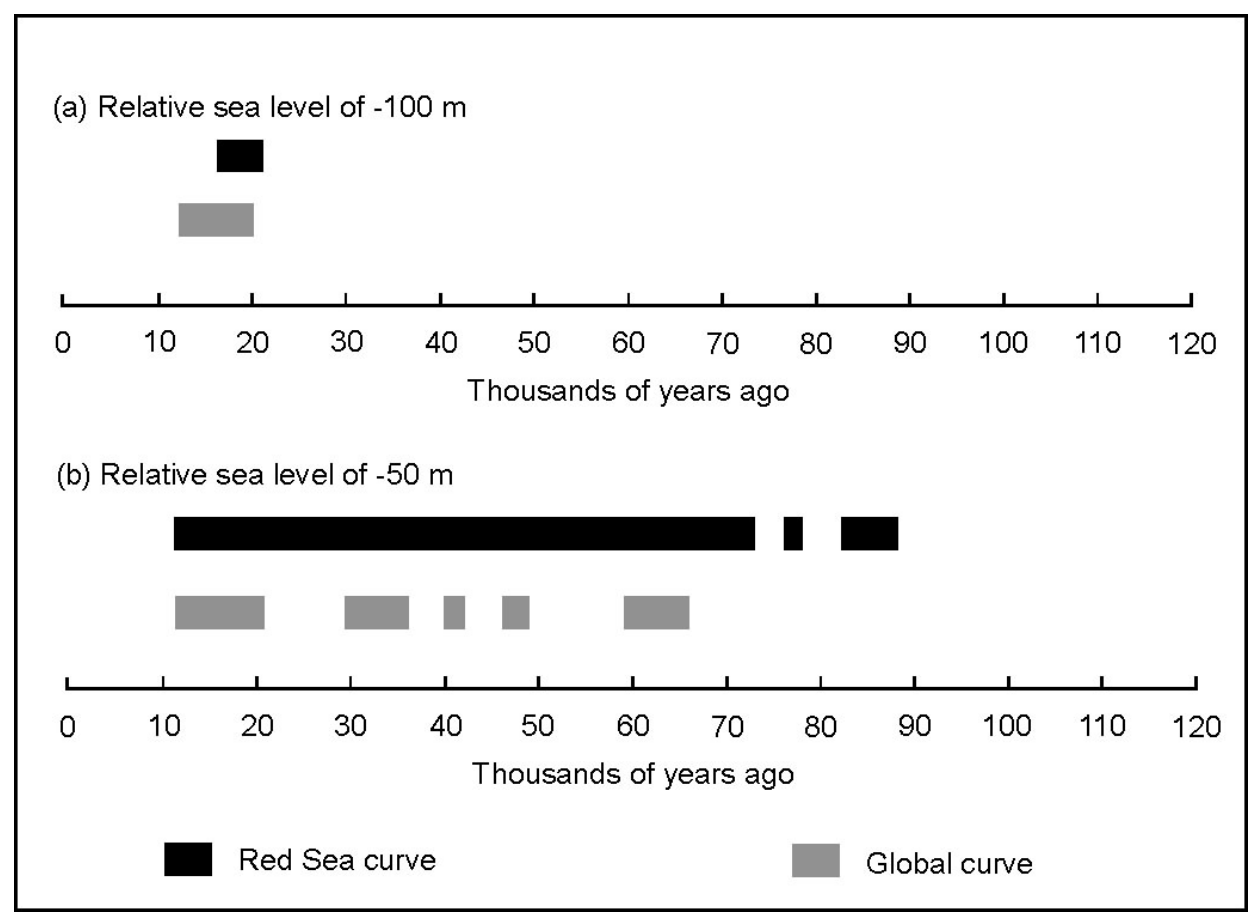

Figure 6. Periods during the past 125,000 years when sea level conditions were most conducive to sea crossings at the southern end of the Red Sea. The upper diagram (a) shows the period when sea level was below $-100 \mathrm{~m}$ according to the Red Sea isotope curve (black) or the global deep-sea isotope curve (gray), and therefore the periods when the channel was at its narrowest and windows of opportunity existed for sea crossings assuming minimal abilities to cross water. The lower diagram (b) shows the periods when sea level was below $-50 \mathrm{~m}$, using the same conventions for sea-level information as in (a), and assumes abilities to cross somewhat wider sea channels than in (a). See Figure 4 for sea level curves and sources of data, Table 1 for dates and durations, and the text for further discussion of assumptions about sea-crossing abilities. (C) G. Bailey.

Before $900 \mathrm{kya}$, the deep-sea record suggests ongoing sea level fluctuations back to at least 2 Mya but a lower amplitude of sea level variation. Again the detailed implications of the isotope record are difficult to interpret, but it seems likely that they indicate a reduced drop in sea level at glacial maxima, and one that most likely did not reach the critical depth threshold of $-100 \mathrm{~m}$, and perhaps not even the $50 \mathrm{~m}$ level. Hence the likelihood of sea crossings in this earlier period without rafts or boats must be much lower, assuming that sea level change resulting from changes in global ice volumes and isostatic adjustments is the only relevant variable. 
Table 1. Periods of potential sea crossing at the southern end of the Red Sea during the last glacial. Dates and durations are in thousands of years. Sea-level curves are taken from Figure 4.

\begin{tabular}{|l|l|l|l|l|}
\hline Sea-level Curve & Sea-level Depth & Duration & $-100 \mathrm{~m}$ & Duration \\
\hline Global & $-50 \mathrm{~m}$ & 16 & $13-21$ & 8 \\
\hline & $11-27$ & 7 & & \\
\hline & $29-36$ & 2 & & \\
\hline & $40-42$ & 3 & & \\
\hline & $46-49$ & 7 & & \\
\hline & $59-66$ & 7 & & \\
\hline Total & & 19 & & 5 \\
\hline & & & $17-22$ & \\
\hline Red Sea & $11-73$ & 62 & & \\
\hline & $76-78$ & 2 & & 13 \\
\hline & $82-88$ & 6 & & \\
\hline Total & & 70 & & \\
\hline
\end{tabular}

However, another variable that potentially affects the width and depth of the southern channel as we go further back into the Pleistocene is tectonic movement. The general effect of rifting is to deepen the floor of the Rift. As we have noted earlier, significant deepening of the Red Sea Rift has occurred since 5 Mya. Edgell (2006, p. 488) uses a figure of $15.6 \mathrm{~mm}$ based on recent GPS measurements for the rate of separation of the Arabian Plate from the African Plate, deducing a land bridge across the Bab alMandab as recently as 1.4 million years ago by simple extrapolation. However, rates of movement, considered in detail in Bailey et al. (2007a), have probably not been constant over this period. Moreover, most of the movement at the southern end of the Red Sea has been taken up by deformation in the highly active Danakil depression of the Afar rather than in the region of the Hanish and Bab al-Mandab channel, which exhibits no significant current activity, and this has probably been the case for the past 2 million years (Ayele et al., 2007; Manighetti et al., 1997), leading to the conclusion that there has been little change in the geometry of the channel over this period with little impact on shoreline reconstruction. Cessation of evaporate formation after 5 million years ago is consistent with this interpretation, suggesting that the Red Sea has maintained a connection with the Indian Ocean since then. While much remains uncertain about the rate of separation between the Arabian and African Plates, the above considerations suggest that there has been relatively little change in the Bab al-Mandab region during the late Pliocene. In conclusion, current understanding of the tectonics in the southern Red Sea region does not alter the above assessment that sea crossings would have been less likely before about 900 kya.

\section{Terrestrial Resources and Paleoclimate}

If human populations had crossed the southern Red Sea at an early period, what sorts of resources would they have found there - how abundant, how easily accessible, how variable and how extensively distributed? The answer to this question can be considered under two main headings: mammalian resources and topographic constraints on their abundance and accessibility; and the timing and effects of climate change. To these we might add a third variable and that is the distribution and availability of raw materials for stone-tool manufacture. Where these are limited in occurrence, they may be a serious disincentive to successful hominin occupation of otherwise productive landscapes (Dennell, 2007). However, many different sorts of materials are quite widely available in the Red Sea region, including basaltic lavas, and a variety of other materials including ferruginous quartzite and other fine-grained siliceous and metamorphic materials. Availability of stone is unlikely to have imposed a serious limiting factor on human settlement or dispersal, although arguably basaltic lavas were a particularly favorable 
material, being easily accessible in appropriately sized nodules on the surface, extensively distributed, and easily worked (Figure 7).

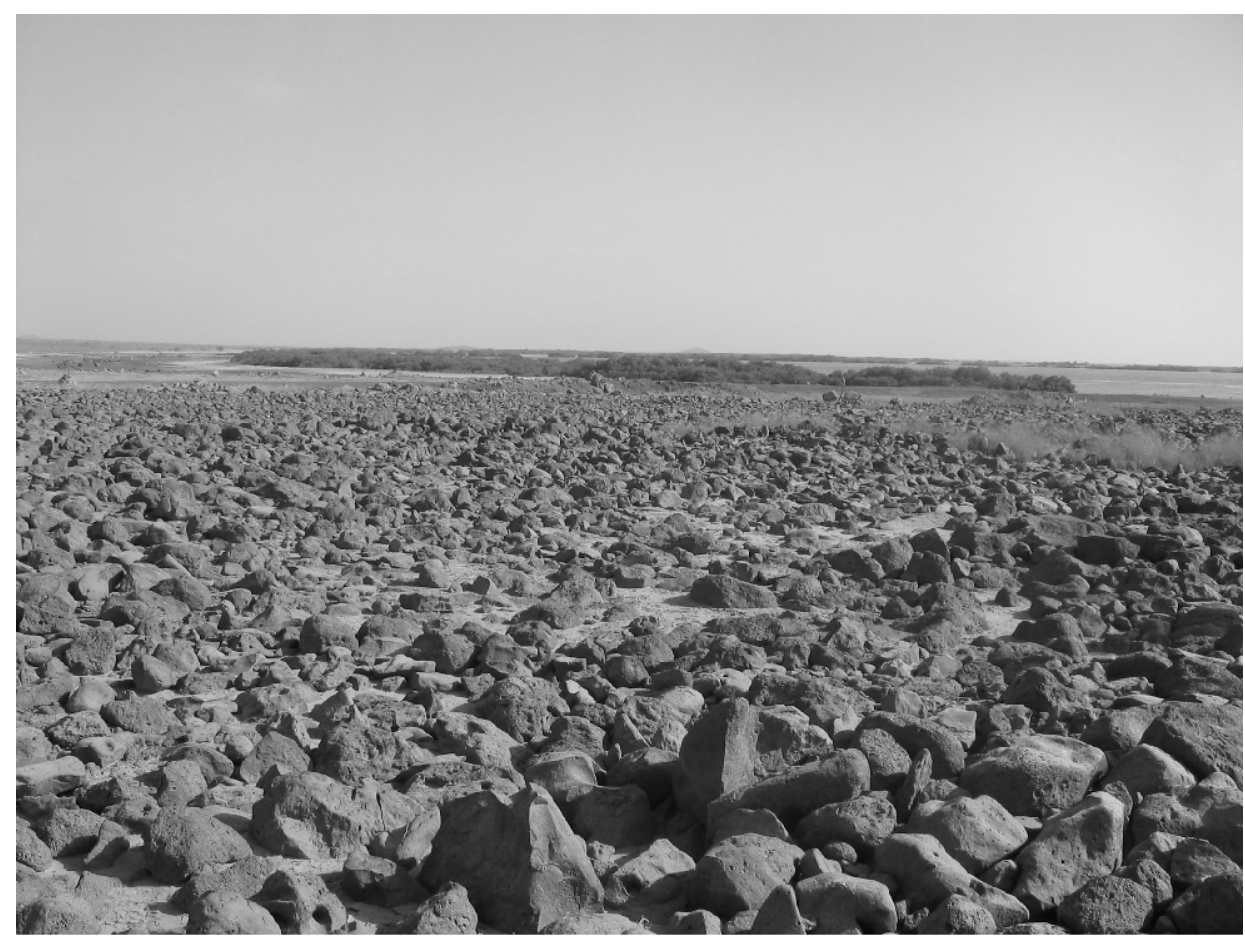

Figure 7. Lava field on the Saudi Arabian coastline in the vicinity of Al Birk. Photo by G. Bailey, March 2004. Worked artifacts and cores are present on the surface, and this is the same site illustrated in Zarins et al. (1981, plate 31A), and referred to by them as site 216-217.

\section{Land Mammals and Topographic Roughness}

Information on past mammalian resources that might have offered potential resources for prehistoric hunters is confined to very limited direct evidence from paleontological or archeological deposits and deductions from present-day species distributions (for more detail, see Turner and O'Regan, 2007). Mammals of medium to large size that exist today in the Arabian Peninsula include oryx, gazelle, Nubian ibex, and rock hyrax, together with a suite of carnivores that includes red fox, wolf, wild cat and leopard (Harrison and Bates, 1991). These are largely limited to semi-desert and rough or mountainous country, reflecting both current climatic conditions and distributions confined by the encroachment of modern human activities.

For past conditions, there are very few archeological or paleontological deposits to provide clues. A small collection of bones $(n=149)$ has been found in stratified context in the Nafud desert associated with paleo-lake conditions (Thomas et al., 1998). Finds include part of a fish maxilla, tortoise, horse (Equus), antelope (Oryx), a trace of elephant, probably the extinct form Elephas recki, a camelid, buffalo (Pelorovis $\mathrm{cf}$. Oldowayensis), hippopotamus, and some indeterminate bovids. The combination of species together with carbon isotope measurements suggests a lake-edge setting surrounded by open savannah and semi-arid grasslands. The authors consider the assemblage to be of Lower Pleistocene date with African affinities. Zarins et al. (1979) and McClure (1978, cited in Zarins et al. 1979), refer to a late Pleistocene fauna in central Arabia and the Rub' al Khali of Bos primigenius, Bubalus (water buffalo), hippopotamus, Equus hemionus, camel and gazelle. From the MIS 5e deposits of Abdur in Eritrea, indeterminate species of elephant, hippo, rhino and bovid have been recorded, but without further detail (Walter et al., 2000). 
This meager evidence at least provides some clues about the sorts of species that we might expect to find in different types of topography (mountains, flat plains) and different climatic conditions. Two factors are critical to past potential: topographic conditions as they affect conditions of local fertility and access by human predators to otherwise elusive prey; and climate change.

Many of the species of animal prey that are of interest to humans are fast moving, dangerous or elusive. Without effective weapons for killing at a distance, humans are at a significant disadvantage compared to other predators. One of the conundrums of human evolution is how early hominins from such a position of disadvantage and with weapons that were initially quite rudimentary were able to target successfully concentrated supplies of animal protein, and make that an expanding part of their diet, of their evolutionary trajectory - particularly in fuelling an extended childhood and a larger brain (cf. Aiello and Wheeler 1995) - and of their ability to extend their habitat range. Scavenging of dead carcasses, clearly implemented at an early stage, eliminates one set of problems in gaining access to otherwise elusive prey, but poses other problems, notably the risk of falling victim to non-human hunters. One solution to this problem lies in the use of complex topography, where localized barriers, narrow or steep valleys, blind canyons, fully or partially enclosed basins of varying size, and rough terrain provide tactical opportunities for an intelligent but unspecialized predator to maneuver and trap prey, out compete other carnivores, and find protection from predators and safety for vulnerable young (King and Bailey, 1985, 2006; Bailey et al., 1993, 2000; King et al., 1994, 1997). Such topographic features are especially characteristic of tectonically active regions. In the African Rift, which is one of the largest and longestlived tectonic structures on the planet, the particular style of tectonics results in the creation and continuous rejuvenation of complex landforms comprising near-vertical fault scarps, lake basins, numerous volcanic cones, extensive lava flows, and a swarm of minor faults and surface irregularities, all of which provide exactly these sorts of topographic opportunities for gaining tactical advantage and protection at the edges of the herbivore-rich savannah plains. As we have recently argued (Bailey et al., 2000; King and Bailey, 2006), the occurrence of some of the earliest and most concentrated fossil and archeological evidence of human evolution in the African Rift may not be merely a coincidence of geological visibility and survival of evidence, but may instead reflect the impact of a distinctive set of topographic conditions that exercised a powerful selective impact on the human evolutionary trajectory with its emphasis on meat-eating, an extended childhood, and wide-ranging bipedalism. Moreover, the sorts of topographic features resulting from active tectonics provide not only tactical advantage in scavenging and hunting, they also create localized basins that trap sediment and water, ranging from the largest lakes of the African Rift to small bodies of water in collapsed calderas, resulting in pockets of fertility of greater or lesser extent, which can sustain plant and animal life even in otherwise relatively arid and disadvantageous climatic conditions.

If these sorts of tectonically related topographic conditions were important in Africa, the question naturally arises as to their wider distribution beyond Africa and their impact on patterns of hominin dispersal. We describe this topographic complexity as topographic 'roughness', a 'rough' surface in this context being an irregular 'corrugated' surface at any geographical scale in contrast to a smooth and flat one. Described in this way, relative roughness can be measured and mapped over large areas using satellite imagery and digital elevation data (see King and Bailey 2006, figure 8a, for a simple example on a global scale using SRTM [Shuttle Radar Topography Mission] 30 data). The basis of the technique lies in the measurement of slope angles from relative height data and the mathematical transformation of this information using Fourier transforms to further smoothe the data for the purpose of creating a colored or shaded map. Additional manipulations of the data can be undertaken to eliminate areas of roughness that are assumed to be inaccessible to hominin occupation because of high altitude or high latitude. Other information such as geological or climatic data can be draped over these roughness maps to help characterize the relative attractions of different areas of landscape.

A 'roughness' map is not the same as a relief map of differential elevations, and it should be emphasized that it is not roughness by itself, but the combination of rough terrain alongside extensive areas of smoother terrain capable of supporting a large herbivore biomass into which the human population can tap, which provides the key to interpretation. Fuller details of the method and its 
application are given elsewhere (King et al., in prep). We use satellite digital elevation data, which is available at different resolutions, and can be enhanced or simplified to highlight roughness at a variety of scales, ranging from mountains and large basins at one end of the spectrum to areas of rough terrain no larger than a football pitch at the other, for example a lava flow that has degraded into an irregular boulder field.

A simple, low-resolution roughness map of the Red Sea is shown in Figure 8, with major lava fields added. Even a cursory examination shows that there is considerable variability in the distribution of roughness, with the most obvious combinations of rough terrain and smooth plains lying on either side of the Ethiopian Plateau, including the Afar Depression and the coastal region of Eritrea, the western and eastern flanks of the Arabian escarpment along its full length from Yemen in the south to the opening of the Jordan Valley in the north, and the Sinai Peninsula.

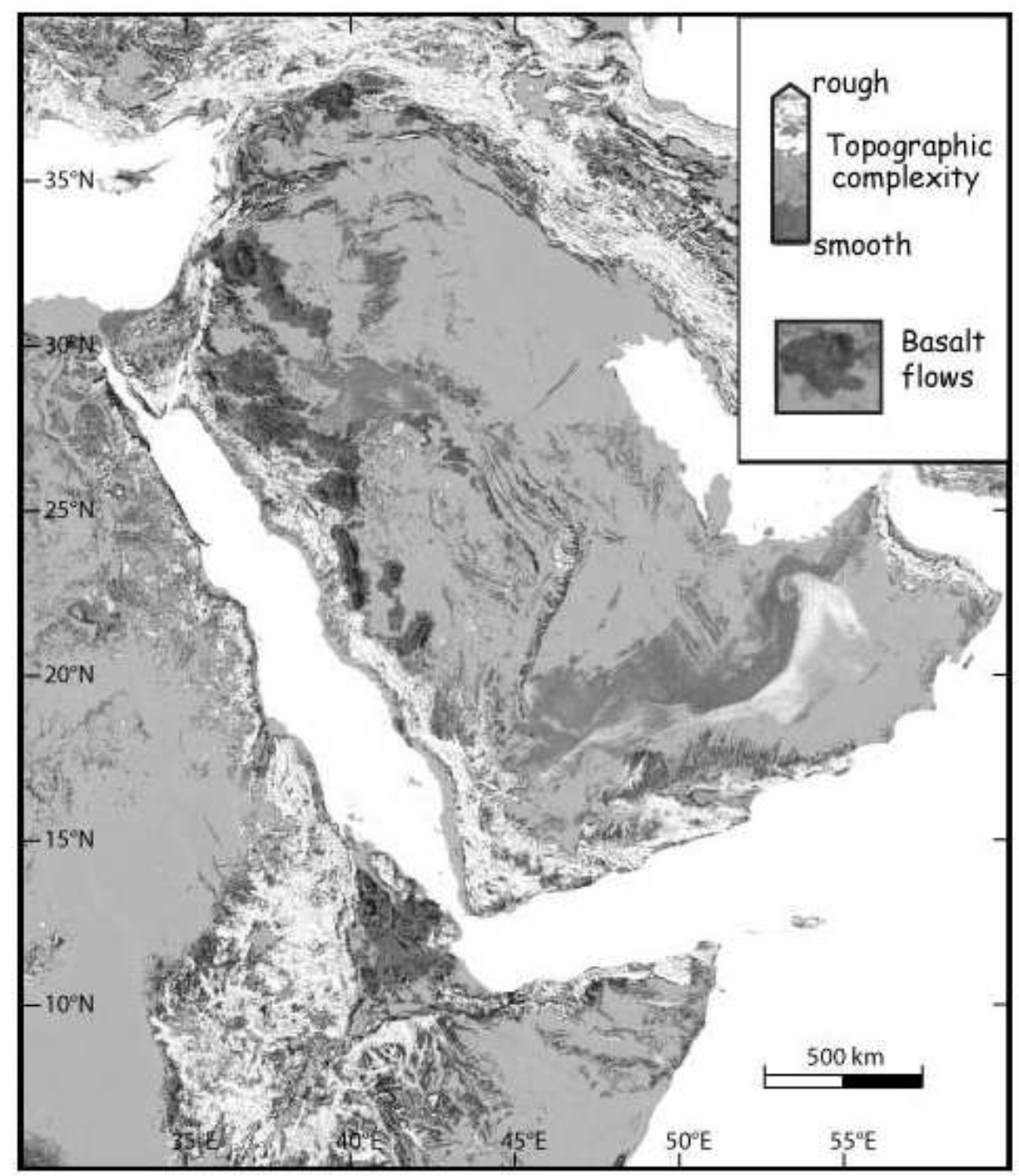

Figure 8. Roughness map of the Red Sea region based on SRTM 30 digital elevation data. The scale ranges from white (very rough) to dark gray (smooth), and the black areas show the distribution of major volcanic lavas. (C) G.C.P. King.

These are also the areas that coincide with the main distribution of the major basaltic lava flows, and these are important not only as a source of easily accessible and workable raw material for making stone tool artifacts, but also as 'safe' areas with small scale roughness and localized patches of fertility into which populations can retreat in the face of threats from predators, competitors, or other crises. Lava fields seem at first sight to represent areas of barren and lifeless terrain, but closer inspection reveals that, 
in amongst the lava cones and boulder fields of degraded lava flows, they are dotted with local patches of fertility where the inherent irregularities of the surface have trapped sediment and water. One does not penetrate far into these lava fields before one encounters such minor 'oases' (Figure 9).

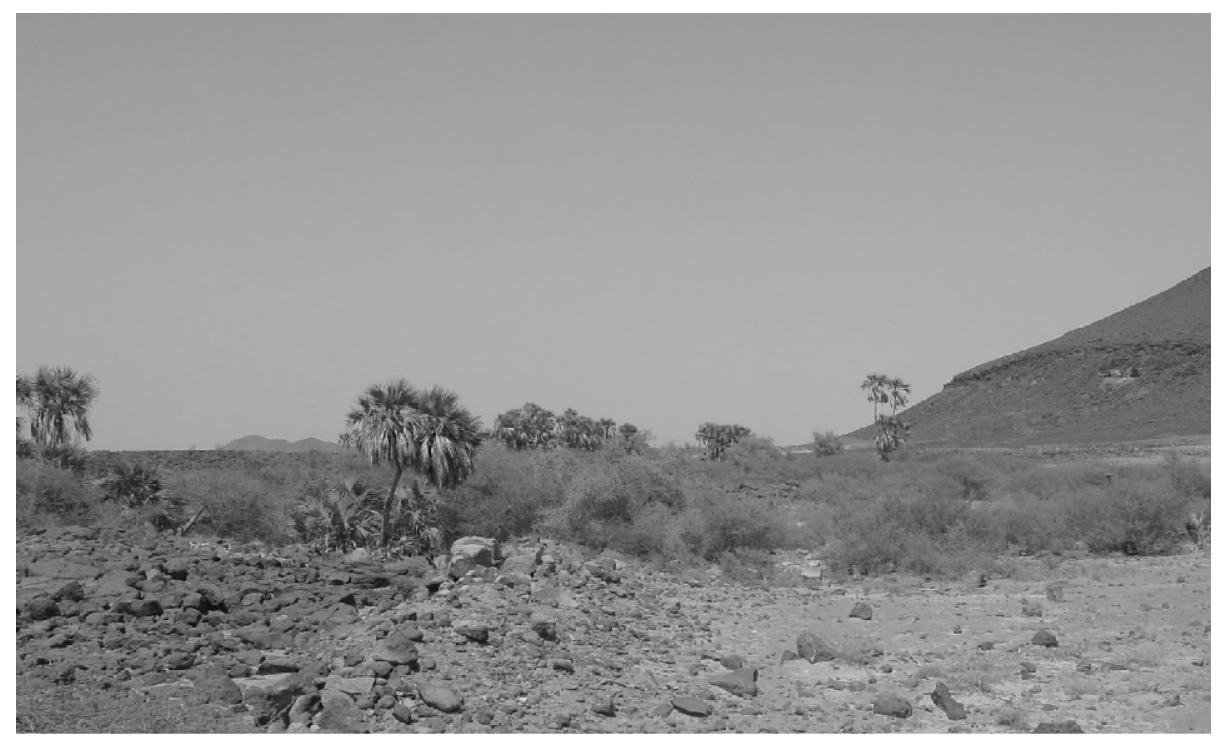

Figure 9. Local area of fertility amidst a volcanic landscape in the hinterland behind Al Birk. Lava fields are in the foreground and middle distance, and volcanic cones in the far distance and on the right. Palm trees and lush vegetation indicate water close to the surface. Photo by G. King, March 2004.

In more extensive and smooth areas one might hypothesize the presence of equids and elephants, along with bovids in wetter conditions or with good surface supplies of water, buffalo and hippo near large areas of standing water such as lakes, and antelopes, gazelle and ibex in semi-arid conditions or rougher terrain.

If one were to plot the core areas likely to have provided the most favorable and enduring conditions for human settlement on the basis of this roughness map, and the most obvious pathways of dispersal, leaving aside questions about the crossing of the Red Sea, the key areas are Eritrea and Afar in the Southwest, and the flanks of the Arabian escarpment. This zone of favorable conditions continues northwards without interruption into the so-called Syrio-Jordanian Rift ${ }^{3}$ and then eastwards along the foothills of the Taurus-Zagros arc.

There is not space here to examine more closely the distribution and interpretation of topographic roughness, or to consider its wider distribution in the Arabian Peninsula. There are extensive fingers of rough terrain that extend into the central Peninsula (visible in Figure 8), and smaller-scale surface irregularities not visible at this resolution but potentially of great significance at the local scale. However, large-scale roughness tends to peter out as one moves eastwards along the southern corridor. On this basis, the primary areas of settlement and movement for earliest hominin settlement and dispersal are likely to have been on a north-south axis between the Afar and the east coast of the Red Sea, extending northwards along the Syrio-Jordanian Rift, and around the Zagros arc to the head of the Gulf region between Arabia and Iran, rather than eastwards by the more direct route along the Indian Ocean coastline. Such an interpretation strengthens the case for a crossing of the southern channel by early human populations, if not by other mammals, but it does not exclude a northerly passageway via the Sinai, and we should remember that the east coast of the Red Sea could have been accessed just as easily from the north as by sea crossings from the Southwest. 


\section{Paleoclimate}

Critical to the above interpretation is a reconstruction of climatic conditions. With more abundant rainfall or surface water supplies we might expect a more diverse range of herbivores, a larger animal biomass, higher human population densities and the possibility of population expansion over a larger territory, particularly to the east of the Arabian escarpment and into central areas of the Arabian Peninsula that are now semi arid or desert, and similarly on the west coast of the Red Sea. With increasing aridity, we would expect populations to thin out, to require larger home ranges and greater mobility, and in the extreme to abandon large areas of territory, and to contract and concentrate in lowland areas with ongoing supplies of water from springs or other sources, or in highland regions with relatively higher rainfall.

On a global scale, glacial periods are generally associated with conditions of increased aridity, given the amount of moisture locked up in the continental ice sheets, and interglacials with wetter conditions. The Red Sea region broadly follows this pattern with good evidence of wettest conditions during interglacial periods (or some part of them) resulting from northward movement of the Indian Ocean Monsoon (Rohling et al., 2002).

However, this is not the full story. Massive alluvial deposits attest to higher volumes of water and stream competence than today, most probably extending far back into the Pleistocene (Jado and Zotl, 1984). Sanlaville (1992) has drawn attention to evidence of higher precipitation than today in many areas, including parts of the central desert and the coastal regions of the Red Sea, in the form of alluvial sediments, travertines, tufas, calcretes, and lake deposits, and has identified four wet phases since the Last Interglacial (see also Edgell, 2006; Parker, this volume). The first, well-dated and corresponding to MIS Stage 5e, ca. $125 \mathrm{kya}$, is the wettest and is followed by a second wet phase representing a renewal of extended monsoon conditions corresponding to Stage 5a. After about 80 kya, arid conditions set in until about $35 \mathrm{kya}$, or possibly earlier, when a new and prolonged phase of increased precipitation took over and extended until about 25-20 kya. These conditions were less wet than in the previous two phases, but were widespread throughout the Peninsula, and included the formation of extensive lakes in the Rub' alKhali (McClure, 1976) and in the Nafud region (Schultz and Whitney, 1986; Arz et al., 2003). Sanlaville attributes this episode to the southward movement of Mediterranean cyclones bringing winter rainfall. There then followed more arid conditions, with widespread dune building, but with brief intervening phases of increased humidity, until the onset of the early Holocene. Between about 9 kya and 7 kya, the Indian Ocean Monsoon extended northwards again and the Rub' al-Khali saw a renewed phase of lake formation (Parker et al., 2004, 2006; Parker, this volume). Mediterranean cyclones also brought increased winter rainfall to northern Arabia and the northern Red Sea region during this period.

Clearly, then, there have been wet-dry fluctuations during both glacial and interglacial periods, though of varying amplitude and periodicity. The wettest and presumably most favorable conditions for plant and animal life on land occurred during interglacial periods of relatively high sea level, typically at sea levels slightly below the present on the evidence of the early Holocene and MIS 5a wet phases, but an extended and relatively humid period also coincided with a large part of MIS stage 3 when sea levels ranged from $-40 \mathrm{~m}$ to more than $-60 \mathrm{~m}$, immediately before the maximum regression, when crossing the southern end of the Red Sea would have been easiest, and possibly overlapping with the beginning of that low sea level stand.. How far this cycle of changes can be extended back into earlier periods of the Pleistocene remains unclear, although there are certainly earlier deposits indicating equivalent conditions of climate wetter than today.

This picture of periodic and quite extensive periods of wetter climate is further enhanced if we take account of environmental conditions in the enlarged coastal region exposed by a drop in sea level. Faure et al. (2002) have argued that as sea level dropped, exposing large areas of the continental shelf, the exit of groundwater from underground aquifers would have greatly increased because of the increased hydrostatic head and the removal of the overlying mass of seawater, which would otherwise tend to inhibit stream flow. Even today some water escapes from these underground sources onto the continental shelf in the form of underwater freshwater springs, and these are well known to local fishermen. At lower sea levels, so Faure et al. (2002) argue, the landscape of the emerged coastal plain would have been 
transformed into coastal wetlands. Hence, plant and animal distributions undergoing contraction in the hinterland because of increased aridity would have found new and more favorable territory into which to expand. This contrast should be qualified by the evidence for formation of massive, linear Pleistocene sand-dunes accumulated during periods of low sea level when marine sands were picked up by wind action from the former sea floor. These dunes are extensively distributed in present-day coastal areas such as the Tihama, where they create a patchwork of sandy areas with little soil formation and sparse vegetation alternating with more fertile alluvial fans or thin soils on bedrock (Munro and Wilkinson, 2007). To what extent these active dunes were spread over the territory exposed by sea-level retreat is unknown, but it seems likely that a similar patchwork existed there too with opportunities for local conditions of soil formation and concentrations of well-watered environments. If this argument is correct, then the periods when local conditions of water supply and plant and animal life were at their most favorable in coastal regions would have coincided with lowest sea levels, when dispersal across the southern end of the Red Sea and around the coastal margins of the Arabian Peninsula would have been easiest.

This notion of coastal wetlands at lowered sea level is, of course, a hypothesis, but it is a testable hypothesis, and especially suitable conditions for testing it can be found in the southern basin of the Red Sea. Here the exposed shelf is relatively shallow and extensive, and would have represented an extension of new territory at lowered sea levels of up to $100 \mathrm{~km}$ in width on either side of the Basin (Figure 2). In the vicinity of the Farasan Islands, even the simplified depth readings available from navigation charts indicate that the islands would have been connected to the mainland at relative sea levels of $-20 \mathrm{~m}$ to $-50 \mathrm{~m}$ (Figure 10). At lower sea levels, the islands would have become part of a complex and varied coastal topography, with deep depressions capable of filling with freshwater, and other surface irregularities that would have facilitated trapping of sediments and water supplies, as well as more extensive areas of flatter coastal plain - in short a combination of rougher and smoother topography with all the consequent advantages described earlier. Moreover, this type of complex topography is also likely to create the most favorable conditions for the protection and preservation under water of terrestrial sediments and archeological materials following inundation by sea level rise. Preliminary underwater investigations have already begun, with the use of sonar soundings and deep diving to identify traces of submerged shorelines (Bailey et al., 2007a, 2007b), and further investigations are planned using the full range of techniques required for underwater survey, including coring, remote sensing and diving.

An insight into the impact of these combined topographic, paleoclimatic and sea-level variables is shown for the region of southwestern Saudi Arabia in the coastal region between Jizan and Al Birk (Figure 11). This coastal region is backed by some of the highest uplands of the Arabian escarpment in the Asir highlands, providing a very wide range of altitudinal conditions over a relatively short distance. It would also have had some of the most extensive coastal lowlands exposed at lowered sea levels. There are important concentrations of sites across this region and in a variety of settings, including the sites around the lava fields of Al Birk and Ash-Shuqayk on the coast, in the coastal hinterland near Abu Arish, in the Asir Highlands near Khamis Mushayt, and on the channels draining eastwards from the Arabian escarpment, notably at Hima and Najran and eastwards into the Rub 'al Khali (Zarins et al. 1981). These sites attest both to the general attractions of the region and the diversity of ecological settings in which early sites occur. In climatic conditions wetter than today, extensive drainage channels would have provided a well-watered landscape with diverse ecologies and a full range of habitats and mammalian resources from the highest mountains down to the coastal plain, and attractive pathways for animal migration and human dispersal along river valleys on both sides of the watershed, linking the coastal region to extensive basins in the Arabaian interior.

Combining this discussion of terrestrial conditions at lowered sea level with deductions from the distribution of topographic roughness and paleoclimates, Figure 12 shows a simple hypothetical model of areas that are likely to have been most favorable to human settlement over the longest period in relation to climate and sea-level change and the other factors discussed earlier. Coastal regions on the wider coastal plains in the south clearly rate highly because of their combination of different resources, their relative proximity to the better-watered uplands of the higher escarpments, extensive areas of rough topography 
and basaltic lavas, and their access to more extensive areas of the continental shelf with their hypothesized wetlands during periods of low sea level. The Northwest sector rates less favorably because of the lower relief, the closer encroachment towards the Red Sea of the desert interior, and the relative lack of high escarpments that could have captured rainfall. One final variable that needs to be factored into this discussion is the availability of marine resources.

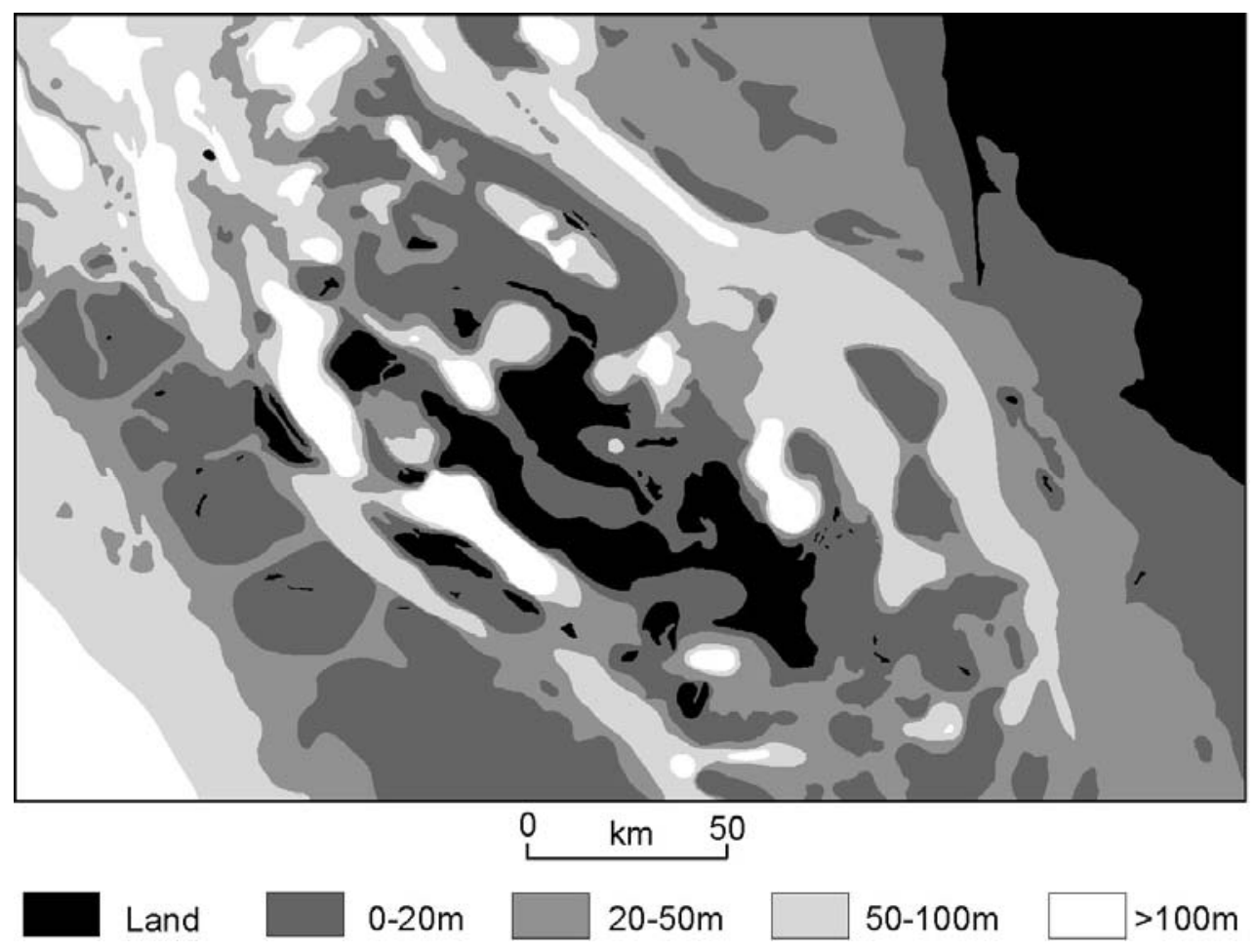

Figure 10. General bathymetry and topography of the submerged landscape in the vicinity of the Farasan Islands. Data compiled by Garry Momber from British Admiralty chart 15. Note the complex and fragmented topography resulting from salt tectonics and the deep depressions offshore of the islands. The largest of the Farasan Islands would have been connected to each other and to the mainland when sea was below about $-50 \mathrm{~m}$ (at approximately 12,000 cal BP during the most recent sea-level rise and at other periods of comparable or lower seas level), forming a single continuous land mass (C) G. Bailey.

\section{Coastal Habitats and Marine Resources}

As on land, so at the shore edge, the most favorable coastlines of the Red Sea Basin for marine resources are in the south, with its extensive areas of shallow shelf, high inputs of nutrients and more moderate salinities. The archipelagos of the Dahlak and Farasan Islands also provide the longest extent of shorelines with access to abundant intertidal and inshore resources. The numerous and substantial shell mounds of the Farasan Islands that have formed during the past six millennia in association with the present sea level give some indication of the archeological signature that one might expect from coastal economies with a high dependence on marine resources (Figure 13). 


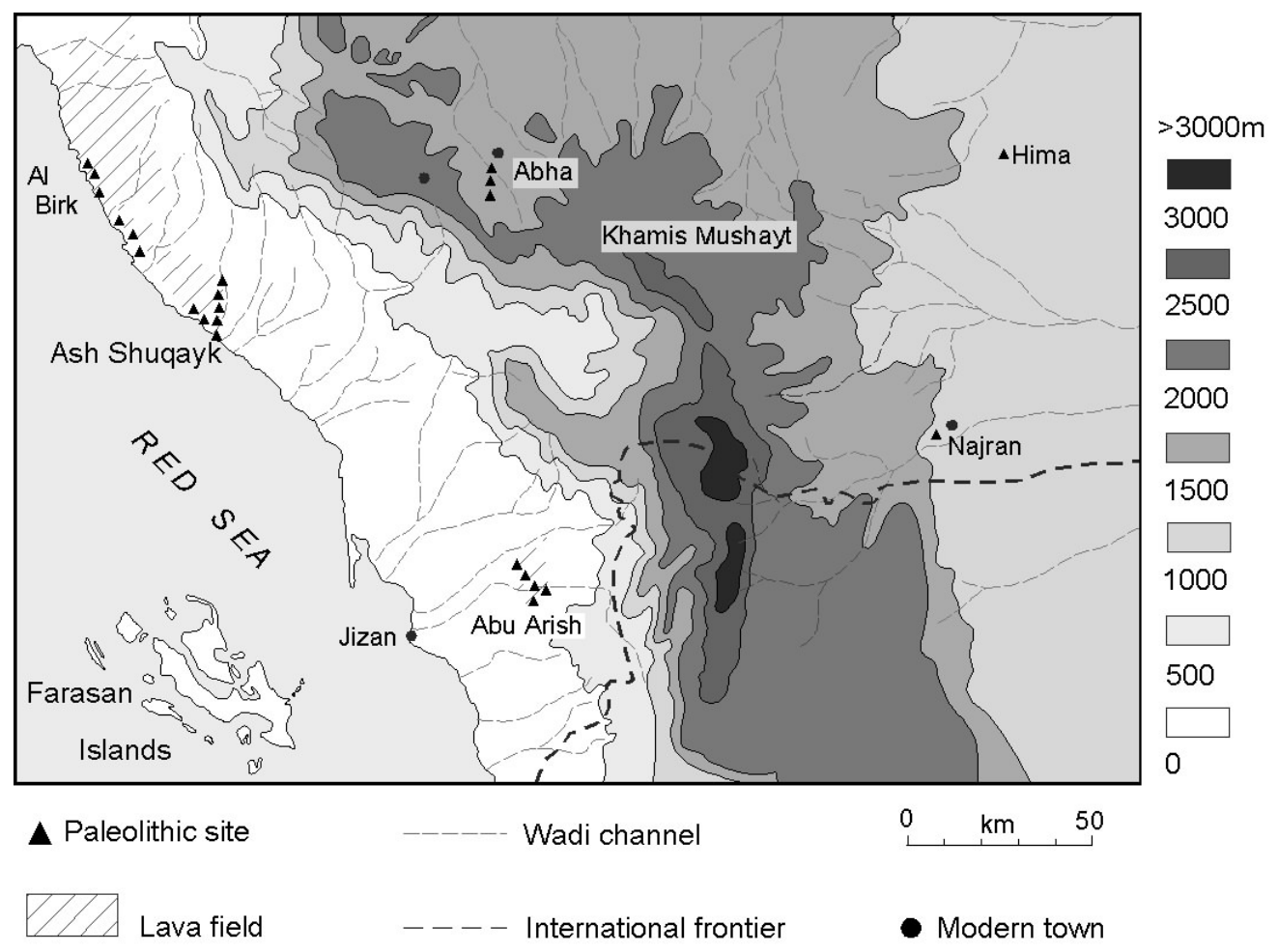

Figure 11. The Arabian escarpment between Al Birk and Jizan showing simple relief, wadis, major lava fields and main concentrations of Paleolithic sites. (C) G. Bailey.

Even these sites, which contain many millions of shells, do not necessarily imply specialized shellfood economies or intensive exploitation of the molluscs, since large numbers of shells are needed to supply a given requirement of food, such mounds are usually accumulated quite slowly and intermittently over many centuries or millennia, and shells are notoriously liable to over-representation in archeological deposits in comparison with other food remains. Similar substantial mounds of a similar time-range are known in their tens of thousands from many other parts of the world, and are invariably associated with broad-spectrum economies that draw on a range of marine and terrestrial resources according to local environmental circumstances (Bailey and Milner 2002). Substantial shell mounds are notoriously rare from earlier periods, most probably in part because of lowered sea levels and the submergence of shoreedge sites, and we would not necessarily expect Pleistocene shell-midden deposits to match the size and density of those well known from the Holocene. Lower human population densities in earlier periods, lack of technological items such as containers and boats, which would have facilitated processing and consumption of larger numbers of shells in one location, and factors of differential preservation and visibility resulting from sea-level change, coastal erosion and weathering, all argue against the survival or visibility of such evidence as one goes further back into the Pleistocene. But the more recent examples do at least provide a benchmark against which to evaluate earlier evidence.

Two issues require further exploration here, the impact of lowered sea levels on resourceproductivity, and the actual evidence that marine resources were exploited in earlier periods and their possible contribution to human settlement.

With reduced inflow from the Indian Ocean during periods of low sea level, salinity in the Red Sea was clearly high enough to inhibit plankton photosynthesis, at least at the maximum low sea-level stand, implying more extensive areas of marine desert than today (Hemleben et al., 1996; Fenton et al., 2000; Siddall et al., 2003). In the south, low sea levels would have reduced the extensive shallow areas of the continental shelf that form such an important nutrient supply and nursery ground for the modern fisheries, presumably with some corresponding reduction in marine productivity. 


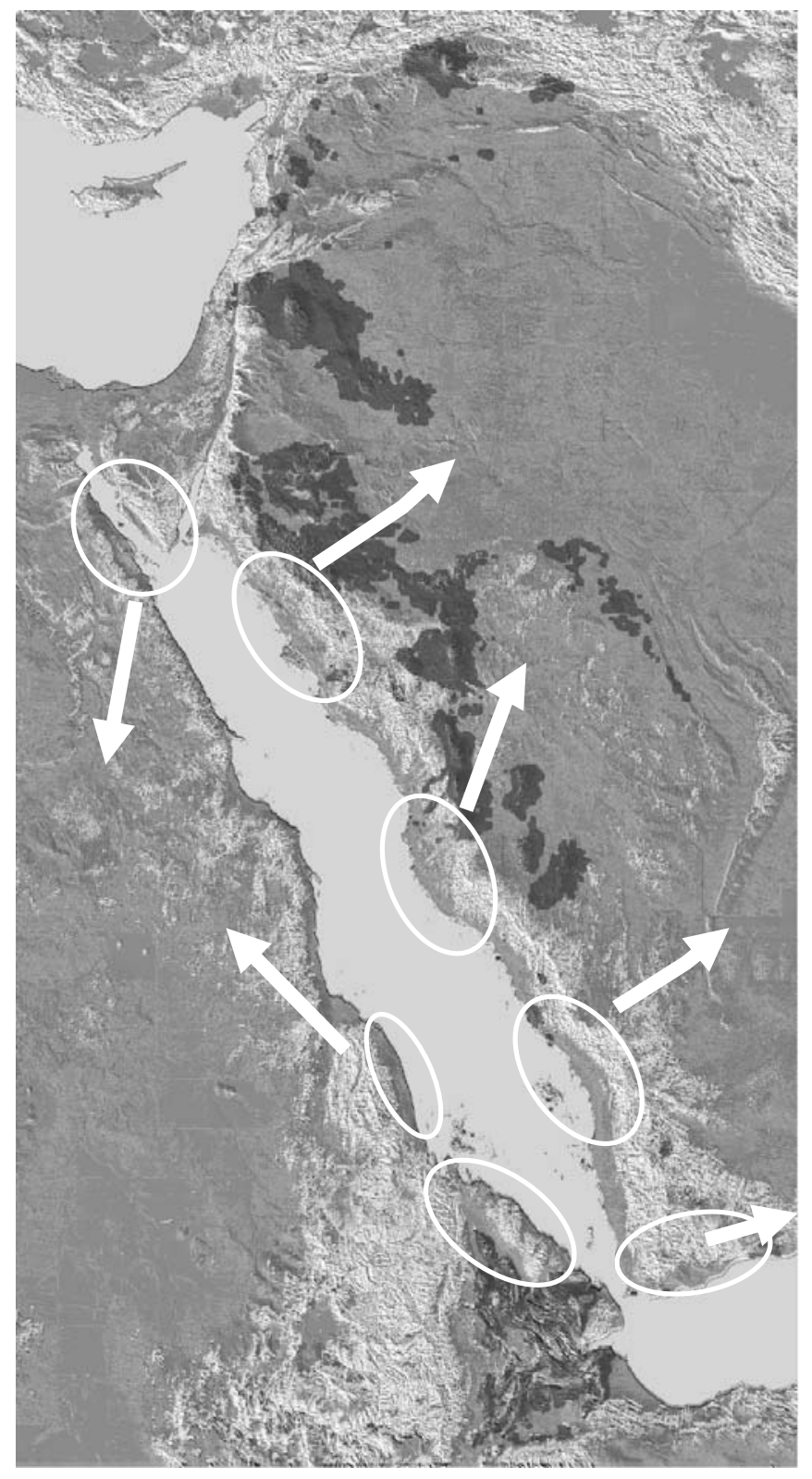

Figure 12. Model of refugia in the Red Sea region. The base map is a map of relative roughness, using the same conventions as in Figure 8.Circles indicate areas with the most varied range of resources and the most persistently favorable conditions for human settlement. Arrows indicate general directions of habitat extension during wetter climatic periods. (C) G.C.P. King and G. Bailey.

However, these effects should not be over-exaggerated. As discussed earlier, many marine organisms are already adapted to conditions of high salinity today, in salinities that may range from 40\%o to $80 \%$ or more (Jones et al., 1987), although the range of marine species becomes increasingly impoverished with increasing salinity, and the evidence of Red Sea endemism indicates that many persisted through the periods of lowest sea level and relative isolation from the Indian Ocean. Many marine animals can also obtain nutrients from plant matter independently of the phytoplankton food chain, particularly reef fish, molluscs, and the predators that feed on them, and these are particularly the marine resources that would have been most accessible to human gatherers on the coast edge. Nevertheless, the productivity and abundance of marine resources would almost certainly have been much reduced during low sea levels, especially in the central and northern sectors of the Red Sea, but even at a reduced level would have offered an additional advantage to human populations living in coastal areas, especially at the southern end of the Basin, in closest proximity to the Gulf of Aden. 


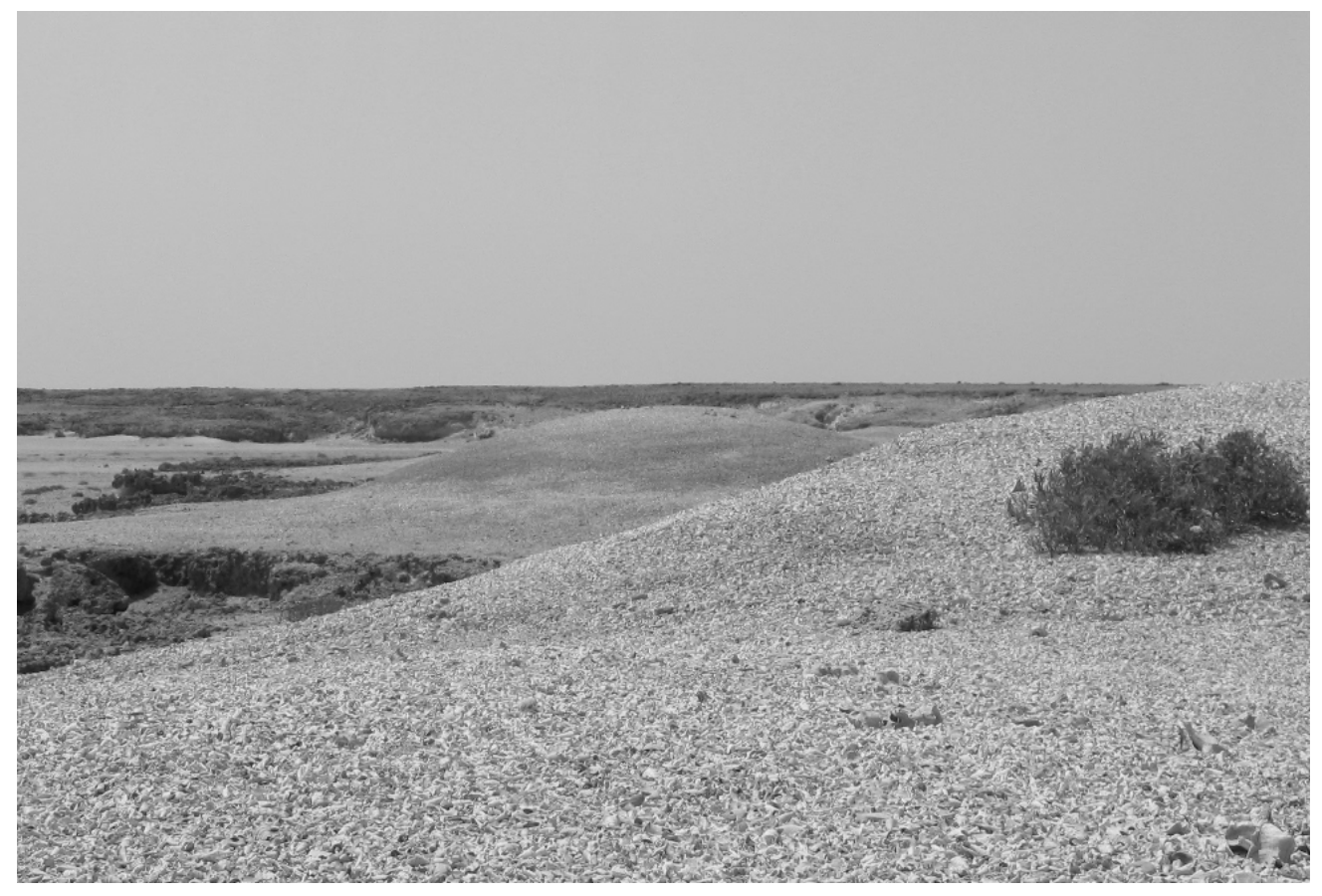

Figure 13. Holocene shell mounds on Qumah Island in the Farasan Islands. Photo by G. Bailey, March 2004.

When we turn to actual evidence of exploitation, the evidence is obscure. Many of the shorelines that might provide relevant evidence are of course under water and have yet to be explored (cf. Bailey et al., 2007a,b). Otherwise, a variety of proxies and evidence of uncertain validity have been relied on. The question of what constitutes a coastal habitat or a coastal economy in the context of human settlement is a matter of definition and is open to considerable differences of opinion. Often the terms are used as very general descriptive labels to refer to any location or archeological site that is within reach of the present-day coastline, a reach that may range from $100 \mathrm{~m}$ or less to $100 \mathrm{~km}$ and more, a descriptive label of such generality as to be devoid of useful analytical content. A strict definition of a coastal economy is one 'devoted, at least more so than not so . . . to the exploitation of marine resources' (Beaton, 1995, p. 802), or, in the absence of precise quantitative measures of the marine component in subsistence, one with clear evidence of material culture items devoted to marine subsistence such as fish hooks, harpoons and boats, dense concentrations of marine food remains, or substantial settlements on the coast edge.

However, people may be attracted to coastal areas and even to the immediate shoreline for reasons that have nothing to do with marine resources, for raw materials washed up on the beach or outcropping nearby to make artifacts, or for terrestrial plant and animal food resources that often occur in coastal areas in greater diversity or abundance because of higher water tables and climatic amelioration relative to the adjacent hinterland. The presence of stone tools on or close to a present-day shoreline, unaccompanied by unequivocal evidence of food remains, by itself can tell us nothing about the nature of the subsistence economy, especially if the artifacts are not well dated and may have been deposited during a period of lower sea level when the contemporaneous shoreline would have been displaced many kilometers seaward.

Even where organic materials are present in association with artifacts, their status as food remains may be ambiguous. This is especially a problem for sites in beach locations, where shells and other marine materials may be accumulated by natural processes, or picked up as dead specimens for use 
as artifacts or ornaments, requiring detailed taphonomic analyses to distinguish natural from cultural accumulations (cf. Bailey et al., 1994; Stiner, 1994, p, 177, 182). This is evidently a problem with the Abdur site, where the oyster shells originally claimed as evidence of food remains (Walter et al., 2000) later turned out to be a natural death assemblage (Bruggemann et al., 2004).

Sites in similar locations to the Abdur site have been recorded along the Saudi Red Sea coastline in association with raised marine terraces and lava fields, with stone tools of Middle Stone Age and Acheulean type, particularly in the lava field between Ash-Shuqayk and Al Birk (Figures 1 and 11; Zarins et al., 1981). The Middle Stone Age material at Al Birk (also referred to as site 216-208) is located on the surface of a coral beach terrace presumed to be of Last Interglacial (MIS Stage 5) date ${ }^{4}$. Zarins et al. (1981) reported tools embedded in the beach deposit, but we were unable to replicate that observation in 2004 either at this site or anywhere else along this stretch of the Red Sea coastline where stone tools have been reported in association with lava fields and coral terraces, although the area has undergone considerable disturbance and damage because of bulldozing activity, road building and other development since the original surveys. It is also clear that the beach terrace at Al Birk is banked up against lava flows from the nearby volcanic cone and stratigraphically later than them (Figure 3, Figure 14), not stratified beneath the lava as originally believed (see Zarins et al., 1981, plate 5A), and this is consistent with $\mathrm{K} / \mathrm{Ar}$ ages of ca. 1.3 Mya for the lava cone (Bailey et al., 2007a,b).

Much has also been made of the appearance of shells and other marine indicators in South African coastal sites located on or close to the present-day shoreline with deposits dating to MIS Stage 5 (see Figure 4), notably at the caves of Die Kelders, Klasies River Mouth and Blombos Cave, and at the open air sites of Sea Harvest and Hoedjies Punt (Avery et al., 1997; Henshilwood et al., 2001; Henshilwood and Marean, 2003; Klein et al., 2004). These date between about 130 kya and 75 kya and contain variable quantities of marine shells, mostly rocky shore species of limpets and mussels, often forming layers of quite dense shell midden, and bones of seals, penguins, and fish. This concentration and visibility of marine indicators reflects the fact that the deposits in question are associated with a period of high sea level when the shoreline was nearby, while the absence of earlier material almost certainly reflects the fact that similar activities carried out during periods of low sea level along this coast would have left their mark in locations that are now far offshore and deeply underwater.

The record on this coastline has recently been extended back to 160 kya by the recently reported finds from the cave of Pinnacle Point (Marean et al., 2007). Here, however, the marine indicators comprise just 79 shells deposited at a time when the site was many kilometers inland from the contemporaneous shoreline during a period of low sea level. This is about what one would expect by way of a visible marine signature in such geographical circumstances. Whether this evidence implies much greater quantities of seafood consumed or processed near the now-submerged shoreline is a matter of debate. Similar small quantities of marine shells are present in European coastal-cave sequences with Upper Paleolithic deposits accumulated during the low sea levels of the last glacial, notably sites of northern Spain, which were up to $10 \mathrm{~km}$ inland at the time (Bailey and Craighead, 2003; Bailey and Milner, 2008).

There is nothing in this evidence to support claims that the African material represents the earliest appearance of marine resources in the human paleoeconomy, or that their consumption signifies the appearance of 'modern' behaviors associated with cognitive developments in later Homo sapiens. Such claims are at risk both of over-exaggerating the significance of marine resources, and of underestimating the problems of differential visibility of relevant evidence as one goes further back into the Pleistocene (cf. Erlandson and Fitzpatrick, 2006). All the marine resources present are consistent with collecting or scavenging on the foreshore or the intertidal zone, and with the simplest levels of technology. Similar evidence has been recovered from sites in Gibraltar and elsewhere in the Mediterranean associated with Neanderthals. At Vanguard Cave in Gibraltar, marine mollusc shells have been recovered from Last Interglacial deposits, along with bones of sea mammals and some fish vertebrae (Finlayson et al., 2006; Finlayson, pers. comm.). Shells are found in other Mousterian coastal deposits in Italy and Spain, and the earliest known evidence, comprising shells and fish spines, is from the 400 kya Mediterranean open-air site of Terra Amata (De Lumley, 1966). The quantity of shells and other remains 
of marine foods in these Mediterranean sites appears to be less than in the African ones, but this probably reflects the fact that the marine productivity of the Mediterranean is generally-speaking relatively low, and especially in the intertidal zone, where the extent of the molluscan habitat is limited by the lack of tidal movement (Fa, 2008).

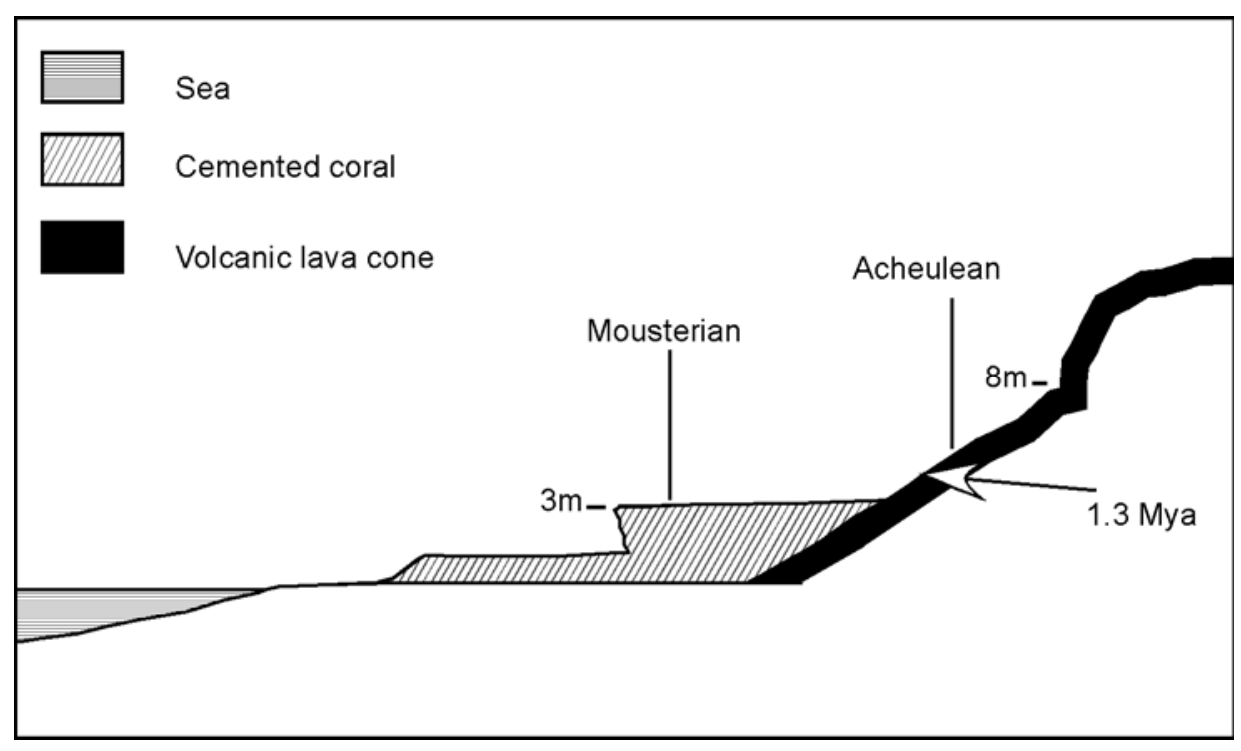

Figure 14. A cross-section of the deposits at Al Birk (206-218). Data from Zarins et al. 1981, plate 5) and from personal observations. The section is viewed looking north, and should be compared with the photograph of the same site in Figure 3. (C) G. Bailey.

None of this is to play down the potential role of marine resources at earlier periods. However, the significance of the few finds available is clearly vulnerable to over interpretation on the flimsiest of evidence. There is no evidence whatsoever that any of these early coastal settlers in these regions during the Pleistocene were marine specialists, or so dependent on marine resources that this provided a spur to migration because of overexploitation of local supplies. Such notions are inherently implausible and there are few if any precedents for them even in the vast ethnographic and archeological literature on coastal hunters and gatherers of recent millennia. Before the advent of specialist technology for offshore fishing and sea-mammal hunting, resources on land would have provided the mainstay of human subsistence, even if resources gathered on the shore provided added advantage to coastal populations. Equally, the belief that marine resources were ignored or avoided until the appearance of modern humans is both factually incorrect and fails to take sufficient account of the loss or invisibility of relevant archeological evidence from earlier periods. The implication that marine resources such as molluscs required some advanced level of human cognition or technology before they were recognized or accessible as edible resources is scarcely credible, given the simplicity with which most molluscs can be collected and consumed, the evidence of their consumption by other animals including other primates, and the omnivorous instincts of humans ${ }^{5}$. The dominant theme of human evolution is adaptive flexibility and omnivory, and it seems more plausible to suggest that marine resources would have been exploited where and when available by human populations living in coastal areas from the earliest period, and that such resources, even if exploited at much lower levels of intensity than in later periods, would have provided some added advantage to those populations that took advantage of them, in combination with plant and animal resources on land. 


\section{Conclusion}

Resource conditions in the Red Sea region and potentials for hominin settlement and movement are clearly quite variable and still subject to a number of uncertainties, especially for the earlier periods of the full time range considered here. The belief that general aridity prevailed during glacial periods and would have deterred all but ephemeral settlement is certainly an oversimplification, and indeed substantially incorrect. There have been quite lengthy episodes of wetter climate throughout the Pleistocene and probably earlier, and not only during interglacial periods. During some part of MIS 3, climate was wet enough to sustain more or less permanent lakes in the desert regions of Saudi Arabia for as much as ten millennia in the period immediately before the glacial maximum (MIS 2). On the coastward side of the Arabian escarpment it is likely that conditions were even more favorable, given the steep relief and the large number of drainage channels that could have supplied water to the coastal lowland. Nevertheless, these wet periods have alternated with lengthy arid periods as well, and much remains to be discovered about their dating and duration and the extent to which local conditions of water supply and fertility may have helped to maintain adequate conditions for human settlement during these arid periods, especially the supply of spring-water from underground aquifers on the coastal plain exposed at the maximum lowering of sea level, a period when general climatic conditions were at their most arid during the glacialinterglacial cycle. Even so, the region as a whole would probably always have lacked long-lasting supplies of surface water comparable to the great lakes of the African Rift and the Jordan Valley or major rivers such as the Nile, The Awash and the Jordan. The extent of territory accessible to human settlement is likely to have undergone regular fluctuations with changing climatic conditions, with core areas or refugia centered on the flanks of the Arabian and Ethiopian escarpments and their adjacent coastal lowlands. Otherwise, given adequate water supplies, the region would have had many attractions in terms of topography, food resources and raw materials for stone-tool manufacture.

The possibilities for human transit across the southern end of the Red Sea also remain uncertain. At no time does there appear to have been an unbroken land connection, at least over the past $400 \mathrm{kya}$, but during periods of maximum sea-level regression during glacial maxima the channel would have been sufficiently narrow to suggest a high likelihood of sea crossings by swimming or simple rafting, at least from the time of the Lower-Middle Pleistocene boundary (ca. 800-900 kya) onwards. Before that the picture is less clear. The amplitude of sea-level variation during the Lower Pleistocene or earlier seems to have been considerably less, but equally the impact of long-term tectonic processes on reconstructions of channel geometry at these earlier periods is harder to specify, though it was probably quite minor, at least back to about 2 Mya, so that the probability of sea crossings was much lower. In any case, sea crossings were probably less significant than the nature of the resources available on either side of the channel, since these could have been reached equally well by population movement from the north.

Finally, the case for marine resources as a primary factor in promoting a process of coastal colonization by early human populations, whether anatomically modern or earlier, remains weak. This is not to say that the hypothesis is wrong. Marine resources, especially those easily accessible close inshore, in the intertidal zone or as carcasses washed up on the beach, would undoubtedly have added to the attractions of the coastal environment, but are unlikely to have provided the basis for specialized marine subsistence economies. Moreover the hypothesis may be more appropriate to some coastal regions than others, and perhaps more so to the coastal regions of Southeast Asia with their archipelagos, rich coastal wetlands and river estuaries (cf. Bulbeck, 2007), than to the coastal environments of the Red Sea, Arabia and adjacent regions. Even so, other conditions in the coastal zone such as water supplies and terrestrial plant and animal resources are likely to have played an equally important or more important role in the attractions of the coastal zone for settlement and dispersal. Either way, the relevant evidence to test these propositions will almost certainly require sustained investigation of the underwater landscape (Bailey and Flemming, 2008), since for most of the period under discussion here sea levels have been persistently lower than the present, and the shorelines and associated paleoenvironmental and archeological evidence of their exploitation are mostly now deeply submerged. 


\section{Acknowledgments}

I am indebted to Abdullah Al-Sharekh, Nic Flemming, Geoffrey King, Kurt Lambeck and Claudio VitaFinzi for discussions of Red Sea archeology, geology and environment, and to NERC through its EFCHED program (Environmental Factors in Human Evolution and Dispersal), the British Academy, the Leverhulme Trust, Saudi Aramco, the Saudi British Bank and Shell Companies Overseas for funding the fieldwork in the southern Red Sea that forms the foundation for this chapter.

\section{References}

Aiello, L.C., Wheeler, P. 1995. The expensive tissue hypothesis: the brain and the digestive system in human and primate evolution. Current Anthropology 36 (2), 199-221.

Amirkhanov, K.A. 1991. The Palaeolithic of Southern Arabia. Nauka, Moscow (in Russian).

Arz, H.W., Lamy, F., Pätzold, J., Müller, P.J., Prins, M. 2003. Mediterranean moisture source for an Early-Holocene humid period in the northern Red Sea. Science 300, 118-21.

Avery, G., Cruz-Uribe, K., Goldberg, P., Grine, F.E., Klein, R.G., Lenardi, M.J., Marean, C.W., Rink, W.J., Schwarcz, H.P., Thackeray, A.I., Wilson, M.L. 1997. Excavations at the Die Kelders Middle and Late Stone Age cave site, South Africa. Journal of Field Archaeology 24 (4): 263-91.

Ayele, A., Jacques, E., Kassim, M., Kidane, T., Omar, A., Tait, S., Nercessian, A., de Chabalier, J.-B., King, G.C.P. 2007. The volcano-seismic crisis in Afar, Ethiopia, starting September 2005. Earth and Planetary Science Letters 255: 177-87.

Bailey, G. In press. Earliest coastal settlement: marine palaeoeconomies, submerged landscapes and human dispersals. In: Anderson, A, Barrett, J, Boyle K (eds.). Global Origins of Seafaring. Cambridge: McDonald Institute for Archaeological Research,

Bailey GN, Craighead A. 2003. Late Pleistocene and early Holocene coastal palaeoeconomies: a reconsideration of the molluscan evidence from Northern Spain. Geoarchaeology: an International Journal 18 (2):175-204.

Bailey, G., Flemming, N. 2008. Archaeology of the continental shelf: marine resources, submerged landscapes and coastal environments in early prehistory. Quaternary Science Reviews 23-24: 2153-65

Bailey, G.N., Milner, N.J. 2002. Coastal hunters and gatherers and social evolution: marginal or central? Before Farming: the Archaeology of Old World Hunter-Gatherers 3-4 (1): 1-15.

Bailey, G., Milner, N., 2008. Molluscan archives from European Prehistory. In: Antczak, A, Cipriani, R (eds.). Early Human Impact on Megamolluscs. British Archaeological Reports International Series 1865. Oxford: Archaeopress, pp. 111-34.

Bailey, G.N., King, G.C.P., Sturdy, D.A. 1993. Active tectonics and land-use strategies: a Palaeolithic example from northwest Greece Antiquity 67, 292-312.

Bailey, G., Chappell, J., Cribb, R. 1994. The origin of Anadara shell mounds at Weipa, North Queensland, Australia. Archaeology in Oceania 29: 69-80.

Bailey, G., King, G., Manighetti, I. 2000. Tectonics, volcanism, landscape structure and human evolution in the African Rift. In: Bailey, G, Charles, R, Winder, N (eds.). Human Ecodynamics: Proceedings of the Association for Environmental Archaeology Conference 1998 held at the University of Newcastle upon Tyne, Oxford: Oxbow, pp. 31-46.

Bailey, G., Lambeck, K., Vita-Finzi, C., Al-Sharekh, A. In prep. Sea-level change and the archaeology of human dispersal in the Red Sea region. Quaternary Science Reviews.

Bailey, G.N., Flemming N., King, G.C.P., Lambeck, K., Momber, G., Moran, L., Al-Sharekh, A., VitaFinzi, C. 2007a. Coastlines, submerged landscapes and human evolution: the Red Sea Basin and the Farasan Islands. Journal of Island and Coastal Archaeology 2 (2): 127-60. 
Bailey, G., Al-Sharekh, A., Flemming, N., Lambeck, K., Momber, G., Sinclair, A., Vita-Finzi, C. $2007 b$. Coastal prehistory in the southern Red Sea Basin, underwater archaeology, and the Farasan Islands. Proceedings of the Seminar for Arabian Studies 37, 1-16.

Beaton, J.M. 1995. The transition on the coastal fringe of Greater Australia. Antiquity 69: 798-806.

Beyin, A. 2006. The Bab al Mandab vs the Nile-Levant: an appraisal of the two dispersal routes for early modern humans Out of Africa. African Archaeological Review 23: 5-30.

Beyin, A., Shea, J. 2007. Reconnaissance of prehistoric sites on the red Sea coast of Eritrea, NE Africa. Journal of Field Archaeology 32: 1-16.

Bonatti, E. 1985. Punctiform initiation of seafloor-spreading in the Red Sea. Nature 316: 33-7.

Bosence, D.W.J., Al-Aawah, M.H., Davison, I., Rosen, B.R., Vita-Finzi, C., Whitaker, E. 1998. Salt domes and their control on basin margin sedimentation: a case study from the Tihama Plain, Yemen. In: Purser, BH, Bosence, DWJ (eds.). Sedimentation and Tectonics of Rift Basins: Red Sea - Gulf of Aden. London: Chapman and Hall, pp. 448-78.

Braithwaite, C.J.R. 1987. Geology and palaeogeography of the Red Sea region. In Edwards, AJ, Head, SM (eds.). Key Environments: The Red Sea. Oxford: Pergamon, pp. 22-44.

Bruggemann, J.H., Buffler, R.T., Guillaume, M.M.M., Walter, R.C., von Cosel, R., Ghebretensae, B.N., Berhe, S.M. 2004. Stratigraphy, palaeoenvironments and model for the deposition of the Abdur Reef Limestone: context for an important archaeological site from the last interglacial on the Red Sea coast of Eritrea. Paleogeography, Palaeoclimatology, Palaeoecology 20: 179-206.

Bulbeck, D. 2007. Where river meets sea: a parsimonious model for Homo sapiens colonization of the Indian Ocean Rim and Sahul. Current Anthropology 48 (2), 315-21.

Butzer, K.W., 1980. Pleistocene history of the Nile valley in Egypt and lower Nubia. In Williams, MAJ, Faure, H (eds.) The Sahara and the Nile. Rotterdam: Balkema, pp. 253-80.

Butzer, K., Hansen, C. 1968. River and Desert in Nubia. Madison: The University of Wisconsin Press,

Caton-Thompson, G. 1953. Some Palaeoliths from South Arabia. Proceedings of the Prehistoric Society 19: 189-218.

Chappell, J., Shackleton, N. J. 1986. Oxygen isotopes and sea level. Nature 324: 137-40.

Dabbagh, A., Hotzl, H., Schnier, H. 1984. Farasan Islands. General considerations and geological structure. In: Jado, AR, Zotl, JG (eds.). Quaternary Period in Saudi Arabia, Volume 2. New York, N.Y.: Springer-Verlag, pp. 212-20.

Darwin, C. 1839. Journal of Researches into the Natural History and Geology of the Countries Visited during the Voyage round the World of H.M.S. 'Beagle' under command of Captain Fitz Roy, R.N. London: John Murray.

De Lumley, H. 1966 Les fouilles de Terra Amata a Nice: premiers resultats. Bulletin de la Musée d' Anthropologie Préhistorique à Monaco 13: 29-51.

Dennell, R. 2007. "Resource-rich, stone poor": early hominin land use in large river systems of Northern India and Pakistan. In Petraglia, M., Allchin, B. (Eds.), The Evolution and History of Human Populations in South Asia. New York, N.Y.: Springer, pp. 41-68.

Dennell, R., Roebroeks, W. 2005. An Asian perspective on early human dispersal from Africa. Nature 438: 1099-1104.

Derricourt, R. 2005. Getting "out of Africa": sea crossings, land crossing and culture in the hominin migrations. Journal of World Prehistory 19(2): 119-32.

Edgell, H.S. 2006. Arabian Deserts. Nature, Origin and Evolution. Springer, Dordrecht, Netherlands.

Edwards, F.J. 1987. Climate and oceanography. In Edwards, A., Head, SM (eds.). Key Environments: The Red Sea. Oxford: Pergamon, pp. 45-69.

Erlandson, J.M., Fitzpatrick, S.M. 2006. Oceans, islands, and coasts: current perspectives on the role of the sea in human prehistory. Journal of Island and Coastal Archaeology 1: 5-32.

Fa, D.A. 2008. Effects of tidal amplitude on intertidal resource availability and dispersal pressure in prehistoric human coastal populations: the Mediterranean-Atlantic transition. Quaternary Science Reviews 23-24: 
Faure, H., Roubet. C. 1968. Découverte d'un biface Acheuléen dans les calcaires marins du golfe Pléistocène de l'Afar (Mer Rouge, Ethiope). Comptes Rendus Hebdomadaires des Seances de l'Académie des Sciences Paris 267: 18-21.

Faure, H., Walter, R.C., Grant, D.R. 2002. The coastal oasis: ice age springs on emerged continental shelves. Global and Planetary Change 33, 47-56.

Felis, T., Pätzold, J., Loya, Y., Fine, M., Nawar, A.H., Wefer, G. 2000. A coral oxygen isotope record from the northern Red Sea documenting NAO, ENSO, and North Pacific teleconnections on Middle East climate variability since the year 1750. Paleoceanography 15: 679-94.

Fenton, M., Geiselhart, S., Rohling, E.J., Hemleben, C. 2000. Aplanktonic zones in the Red Sea. Marine Micropaleontology 40: 277-94.

Fernandes, C.A., Rohling, E.J. Siddal, M. 2006. Absence of post-Miocene Red Sea land bridges: biogeographic implications. Journal of Biogeography 33, 961-6.

Field, J.S., Lahr, M.M. 2005. Assessment of the southern dispersal: GIS based analyses of potential routes at oxygen isotope stage 4. Journal of World Prehistory 19: 1-45.

Field, J.S., Petraglia, M.D., Lahr, M.M. 2007. The southern dispersal hypothesis and the South Asian archaeological record: examination of dispersal routes through GIS analysis. Journal of Anthropological Archaeology 26 (1): 88-108.

Finlayson, C., Giles Pacheco, F., Rodríguez Vidal, J., Fa, D.A., Gutierrez López, M., Santiago Pérez, A., Finlayson, G., Allue, E., Baena Preysler, J., Cáceres, I., Carrión, J., Fernández Jalvo, Y., GleedOwen, C.P., Jimenez Espejo, F.J., López, P., López Sáez, J.A., Riquelme Cantal, J.A., Sánchez Marco, A., Giles Guzman, F., Brown, K., Fuentes, N., Valarino, C.A., Villalpando, A., Stringer, C.B., Martinez Ruiz, F., Sakamoto, T. 2006. Late survival of Neanderthals at the southernmost extreme of Europe. Nature 443: 850-3.

Flemming, N., Bailey, G., Courtillot, V., King, G., Lambeck, K., Ryerson, F., Vita-Finzi, C. 2003. Coastal and marine palaeo-environments and human dispersal points across the Africa-Eurasia boundary. In: Brebbia, CA Gambin, T (eds.). The maritime and underwater heritage. Southampton: Wessex Institute of Technology Press, pp. 61-74.

Forster, P., Matsumura, S., 2005. Did early humans go north or south? Science 308: 965-6.

Frazier, J.G., Bertram, C.B., Evans, P.G.H. 1987. Turtles and marine mammals. In: Edwards, AJ, Head, SM (eds.). Key Environments: The Red Sea. Oxford: Pergamon, pp. 288-314.

Gilmore, M., Al-Ibrahim, M., Murad, A.S. 1982. Part I: Comprehensive Archaeological Survey Program: 1 - Preliminary report on the Northwestern and Northern Regions survey 1981 (1401). Atlal, the Journal of Saudi Arabian Archaeology 6: 9-23.

Girdler, R.W., Styles, P. 1974. Two stage Red Sea floor spreading. Nature 247: 7-11.

Girdler, R.W., Whitmarsh, R.B. 1974. Miocene evaporites in Red Sea cores, their relevance to the problem of the width and age of oceanic crust beneath the Red Sea. Initial Report of the Deep Sea Drilling Program 23: 913-21.

Gvirtzman, G. 1994. Fluctuations of sea level during the past 400,000 years: the record of Sinai, Egypt (northern Red Sea). Coral Reefs 13: 203-14.

Harrison, D.L., Bates, P.J.J., 1991. The Mammals of Arabia. Sevenoaks, England: Harrison Zoological Museum.

Head, S.M. 1987a. Introduction. In: Edwards, AJ, Head, SM (eds.). Key Environments: The Red Sea. Oxford: Pergamon, pp. 1-21.

Head, S.M. 1987b. Red Sea fisheries. In Edwards, AJ, Head, SM (eds.). Key Environments: The Red Sea. Oxford: Pergamon, pp. 363-82.

Hemleben, C., Meischner, D., Zahn, R., Almogi-Labin, A., Erlenkeuser, H., Hiller, B. 1996. Three hundred eighty thousand year long stable isotope and faunal records from the Red Sea: influence of global sea level change on hydrography. Paleoceanography 11 (2): 147-56.

Henshilwood, C.S., Marean, C.W. 2003. The origin of modern behavior: critique of the models and their test implications. Current Anthropology 44 (5), 627-51. 
Henshilwood, C.S., Sealy, J.C., Yates, R., Cruz-Uribe, K., Goldberg, P., Grine, F.E., Klein, R.G., Poggenpoel, C., van Niekerk, K., Watts, I. 2001. Blombos Cave, southern Cape, South Africa: preliminary report on the 1992-1999 excavations of the Middle Stone Age levels. Journal of Archaeological Science 28 (4): 421-48.

Hubert-Ferrari, A., King, G.C.P., Manighetti, I., Armijo, R., Meyer B., Tapponnier, P. 2003. Long-term elasticity in the continental lithosphere: modelling the Aden Ridge propagation and the Anatolian extrusion process. Geophysical Journal International 153: 111-32.

Ingraham, M., Johnson, T., Rihani, B., Shatla, I. 1981. Preliminary report on a reconnaissance survey of the Northwestern Province (with a note onn a brief survey of the Northern Province). Atlal, the Journal of Saudi Arabian Archaeology 5: 59-84.

Jado, A.R., Zotl, J.G. (Eds.). 1994. Quaternary Period in Saudi Arabia, Volume 2. New York, N.Y.: Springer-Verlag.

James, H.V.A., Petraglia, M.D. 2005. Modern human origins and the evolution of behavior in the later Pleistocene record of South Asia. Current Anthropology 46 (Supplement): S3-S27.

Johanson D.C., Taieb M. 1976. Plio-Pleistocene hominid discoveries in Hadar, Ethiopia. Nature 260: 293-7.

Jones, D.A., Ghamrawy, M., Wahbeh, M.I. 1987. Littoral and shallow subtidal environments. In Edwards, AJ, Head, SM (eds.). Key Environments: The Red Sea. Oxford: Pergamon, pp. 169-93.

Killick, A., Whalen, N., James, N., Morsi, G., Kamal, M. 1981. Saudi Arabian archaeological reconnaissance 1980. Preliminary report on the Western Province survey. Atlal, the Journal of Saudi Arabian Archaeology 5: 43-58.

King, G., Bailey, G. 1985. The palaeoenvironment of some archaeological sites in Greece: the influence of accumulated uplift in a seismically active region. Proceedings of the Prehistoric Society 51: 273-82.

King, G.C.P., Bailey, G.N. 2006. Tectonics and Human Evolution. Antiquity 80 (308): 265-86.

King, G.C.P., Bailey, G.N., Sturdy, D.A. 1994. Active tectonics, complex topography and human survival strategies. Journal of Geophysical Research 99, B10: 20063-78.

King, G., Sturdy, D., Bailey, G. 1997. The tectonic background to the Epirus landscape. In: Bailey, G (ed.). Klithi: Palaeolithic Settlement and Quaternary Landscapes in Northwest Greece: Volume 2: Klithi in its local and regional setting. Cambridge: McDonald Institute for Archaeological Research, pp. 541-59.

Klein, R.G., Avery, G., Cruz-Uribe, K., Halkett, D., Parkington, J.E., Steele, T., Volman, T.P. Yates, R. 2004. The Ysterfontein 1 Middle Stone Age site, South Africa, and early human exploitation of coastal resources. Proceedings of the National Academy of Sciences 101 (16): 5708-15.

Lahr, M., Foley, R. 1994. Multiple dispersals and modern human origins. Evolutionary Anthropology 3 (2): 48-60.

Lamb HF, Bates CR, Coombes PV, Marshall MH, Umer M, ${ }^{c}$ Davies SJ, Dejen E. 2007. Late Pleistocene desiccation of Lake Tana, source of the Blue Nile. Quaternary Science Reviews 26 (3-4): 287-299.

Lambeck, K. 2004. Sea-level change through the last glacial cycle: geophysical, glaciological and palaeogeographic consequences. Comptes Rendus Geoscience 336: 677-89.

Lambeck, K., Chappell, J. 2001. Sea level change through the last glacial cycle. Science 292, 679-86.

Lordkipanidze, D., Bar-Yosef, O., Otte, M. (Eds.). 2000. Early Humans at the Gates of Europe: Proceedings of the First International Symposium, Dmanisi, Tbilisi (Georgia) September 1998. Etudes et Recherches Archéologiques de l'Université de Liège (E.R.A.U.L.), Liège, 92.

Macaulay, V., Hill, C., Achilli, A., et al. 2005. Single, rapid coastal settlement of Asia revealed by analysis of complete mitochondrial genomes. Science 308: 1034-6.

McClure, H. 1976. Radiocarbon chronology of late Quaternary lakes in the Arabian Desert. Nature 263: $755-6$.

McClure HA. 1978. Al-Rub al-Khali. In: Sayari S, Zötl J (eds). Quaternary Period in Saudi Arabia. New York, N.Y.: Springer, pp. 252-263. 
Mannino, M.A., Thomas, K.D. 2002. Depletion of a resource? The impact of prehistoric human foraging on intertidal mollusc communities and its significance for human settlement, mobility and dispersal. World Archaeology 33: 452-74.

Manighetti, I., Tapponnier, P., Courtillot, V., Gruszow, S., Gillot, P. 1997. Propagation of rifting along the Arabia-Somalia plate boundary: the Gulfs of Aden and Tadjoura. Journal of Geophysical Research 102: 2681-710.

Marean CW, Bar-Matthews M, Bematchez J, Fisher E, Goldberg P, Herries AR, Jacobs Z, Jerardino A, Karkanas P, Minichillo T, Nilssen P, Thompson E, Watts I, Williams HM. 2007. Early human use of marine resources and pigment in South Africa during the Middle Pleistocene. Nature 449: 905909.

Mastaller, M. 1987. Molluscs of the Red Sea. In Edwards, AJ, Head, SM (eds.). Key Environments: The Red Sea. Oxford: Pergamon, pp. 194-214.

Mellars, P.A. 2006. Going east: new genetic and archaeological perspectives on the modern human colonization of Eurasia. Science 313: 796-800.

Munro, R.N., Wilkinson, T.J. 2007. Environment, landscapes and archaeology of the Yemeni Tihāmah. In Starkey, J., Starkey, P., Wilkinson, T. (Eds.), Natural Resources and Cultural Connections of the Red Sea. British Archaeological Reports International Series 1661. Oxford: Archaeopress, pp.1333.

Omar, G. I., Steckler, M.S. 1995. Fission track evidence on the initial rifting of the Red Sea: Two pulses, no propagation. Science 270: 1341-4.

Oppenheimer, S. 2003. Out of Eden: the Peopling of the World. London: Constable.

O'Regan, H. 2008. The Iberian Peninsula - corridor or cul de sac? Mammalian faunal change and possible routes of dispersal in the last 2 million years. Quaternary Science Reviews 23-24:.

Ormond, R.F.G., Edwards, A.J. 1987. Red Sea fishes. In: Edwards, AJ, Head, SM (eds.). Key Environments: The Red Sea. Oxford: Pergamon, pp. 251-87.

Parker, A.G., Eckersely, L., Smith, M.M., Goudie, A.S., Stokes, S., Ward, S., White, K., Hodson, M.J. 2004. Holocene vegetation dynamics in the northeastern Rub' al-Khali desert, Arabian Peninsula: a phytolith, pollen and carbon isotope study. Journal of Quaternary Science 19 (7): 665-76.

Parker, A.G., Goudie, A.S., Stokes, S., White, K., Hodson, M.J., Manning, M., Kennet, D. 2006. A record of Holocene climate change from lake geochemical analyses in southeastern Arabia. Quaternary Research 66 (3): 465-76.

Petraglia, M. 2003. The Lower Palaeolithic of the Arabian Peninsula: occupations, adaptations, and dispersals. Journal of World Prehistory 17, 141-79.

Petraglia, M. 2007. Mind the gap: factoring the Arabian Peninsula and the Indian subcontinent into Out of Africa models. In Mellars, P, Boyle, K, Bar-Yosef, O, Stringer, C (eds.) Rethinking the Human Revolution. Cambridge: McDonald Institute for Archaeological Research, Cambridge, pp. 383-94.

Petraglia, M., Alsharekh, A. 2003. The Middle Palaeolithic of Arabia: Implications for modern human origins, behaviour and dispersals. Antiquity 77 (298): 671-84.

Plaziat, J.-C., Baltzer, F., Choukroi, A., Conchon, O., Freytet, P., Orszag-Sperber, F., Raguideau, A., Reyss, J.-L. 1998. Quaternary marine and continental sedimentation in the northern Red Sea and Gulf of Suez (Egyptian coast): influences of rift tectonics, climatic changes and sea-level fluctuations. In: Purser, BH, Bosence, DWJ (eds.). Sedimentation and Tectonics of Rift Basins: Red Sea - Gulf of Aden. London: Chapman and Hall, pp. 537-73.

Rohling, E.J., Cane, T.R., Cooke,S., Sprovieri, M., Bouloubassi, I., Emeis, K.C., Schiebel, R., Kroon, D., Jorissen, F.J., Lorre, A., Kemp, A.E.S. 2002. African Monsoon variability during the previous interglacial maximum. Earth and Planetary Science Letters 6304: 1-15.

Ron, H., Levi, S. 2001. When did hominids first leave Africa? New high-resolution palaeomagnetic evidence from the Erk-El-Ahmar formation, Israel. Geology 29: 887-90.

Rose, J.I. 2004. The question of Upper Pleistocene connections between East Africa and South Arabia. Current Anthropology 45(4): 551-5. 
Sanlaville, P. 1992. Changements climatiques dans la Péninsule Arabique durant le Pléistocène Supérieur et l'Holocène. Paléorient 18 (1): 5-26.

Schultz, E., Whitney, J.W. 1986. Upper Pleistocene and Holocene lakes in the An Nafud, Saudi Arabia. Hydrobiologia 143: 175-90.

Shackleton, N.J. 1987. Oxygen isotopes, ice volume and sea level. Quaternary Science Reviews 6: 18390.

Siddall, M., Smeed, D.A., Matthiesem, S., Rohling, E.J. 2002. Modelling the seasonal cycle of the exchange flow in Bab el Mandab (Red Sea). Deep-Sea Research I: 1551-69.

Siddall, M., Rohling, E.J., Almogi-Labin, A., Hemleben, C., Meischner, D., Schmelzer, I., Smeed, D.A. 2003. Sea-level fluctuations during the last glacial cycle. Nature 423, 853-8.

Stiner, M.C. 1994 Honor among thieves: a zooarchaeological study of Neandertal ecology. Princeton, NJ: Princeton University Press.

Stringer C. 2000. Coasting out of Africa. Nature 405:53-55.

Stringer CB, Finlayson JC, Barton RNE, Fernández-Jalvo Y, Cáceres I, Sabin RC, Rhodes EJ, Currant AP, Rodríguez-Vidal J, Giles-Pacheco F, Riquelme-Cantal JA. 2008. Neanderthal exploitation of marine mammals in Gibraltar. Proceedings of the Nationall Academny of Sciences 105 (38):14319-14324

Taviani, M. 1998. Post-Miocene reef faunas of the Red Sea: glacio-eustatic controls. In Purser, BH, Bosence, DWJ (eds.). Sedimentation and Tectonics of Rift Basins: Red Sea - Gulf of Aden. London: Chapman and Hall, pp. 574-582.

Tchernov, E. 1992. Eurasian-African biotic exchanges through the Levantine corridor during the Neogene and Quaternary. In von Koenigswald W, Werdelin, L (eds.). Mammalian Migration and Dispersal Events in the European Quaternary. Frankfurt am Mein: Courier Forschung-Institut Senckenberg, pp.103-23.

Templeton, A. 2002. Out of Africa again and again. Nature 415: 45-51

Thangaraj, K., Chaubey, G. et al. 2005. Reconstructing the origin of Andaman Islanders. Science 308: 996.

Thomas H, Geraads D, Janjou D, Vaslet D, Memesh A, Billiou D, Bocherens H, Dobigny G, Eisenmann V, Gayet M, de Lapparent de Broin F, Petter G, Halawani M. 1998. First Pleistocene faunas from the Arabian Peninsula: An Nafud desert, Saudi Arabia. Comptes Rendus de l'Academie des Sciences Series IIA Earth and Planetary Science 226 (2):145-152

Turner, A., O'Regan, H. 2007. Afro-Eurasian mammalian fauna and early hominin dispersals. In: Petraglia, M, Allchin, B (eds.). The Evolution and History of Human Populations in South Asia. New York, N.Y.: Springer, pp. 23-39.

Van Andel T.1989. Late Quaternary sea-level changes and archaeology. Antiquity 63: 733-45.

Van Peer, P, 1998. The Nile corridor and the Out-of-Africa model: an examination of the archaeological record. Current Anthropology 39, Supplement: 115-40.

Vermeersch, P.M. 2001. 'Out of Africa' from an Egyptian point of view. Quaternary International 75: 103-12.

Walter, R.C., Buffler, R.T., Bruggemann, J.J., Guillaume, M.M.M., Berhe, S.M., Negassi, B., Libsekal, Y., Cheng, H., Edwards, R.L., von Gosel, R., Neraudeau, D., Gagnon, M. 2000. Early human occupation of the Red Sea coast of Eritrea during the Last Interglacial. Nature 405: 65-9.

Warren, J.K. 1999. Evaporites, their Evolution and Economics. Oxford: Blackwell.

Weikert, H., 1987. Plankton and the pelagic environment. In Edwards, AJ, Head, SM (eds.). Key Environments: The Red Sea. Oxford: Pergamon, pp. 90-111.

Wendorf, F. 1976. Prehistory of the Nile Valley .London and New York: Academic Press.

Wendorf, F., Marks, A. 1968. Prehistory of Nubia. Dallas: Fort Burgwin Research and Southern Methodist University.

Whalen, N.M., Fritz, G.A., 2004. The Oldowan in Arabia. Adumatu 9: 7-18.

Whalen, N.M., Siraj-Ali, J.S., Davis, W., 1984. Excavation of Acheulean sites near Saffaqah, Saudi Arabia, 1403 AH 1983. Atlal, the Journal of Saudi Arabian Archaeology 8: 9-24. 
Whalen, N.M., Wilbon, P.D., Pease, D.W., 1989. Early Pleistocene migrations into Saudi Arabia. Atlal, the Journal of Saudi Arabian Archaeology 12: 59-75.

Whalen, N.M., Sindi, H., Wahidah, G., Siraj-Ali, J.S. 1983. Excavation of Acheulean sites near Saffaqah in al-Dawadmi (1402/1982). Atlal, the Journal of Saudi Arabian Archaeology 7: 9-21.

Whalen, N.M., Siraj-Ali, J.S., Sindi, H., Pease, D.W., 1986. A Lower Pleistocene site near Shuwayhitiyah in northern Saudi Arabia. Atlal, the Journal of Saudi Arabian Archaeology 10: 94-101.

Whalen, N.M., Siraj-Ali, J., Sindi, H.O., Pease, D.W., Badein, M.A., 1988. A complex of site in the Jeddah-Wadi Fatimah area. Atlal, the Journal of Saudi Arabian Archaeology 11: 77-85.

White, T., B. Asfaw, D. DeGusta, Gilbert, H. Richards, D.G., Suwa, G. et al., 2003. Pleistocene Homo sapiens from Middle Awash, Ethiopia. Nature 423: 742-7.

Woldegabriel, G., White, T.D., Suwa, G., Renne, P, de Heinzelin, J, Hart, W.H., Helken, G., 1994. Ecological and temporal placement of early Pliocene hominids at Aramis, Ethiopia. Nature 371 (22): 330-3.

Zarins, J., Ibrahim, M., Potts, D., Edens, C., 1979. Saudi Arabian archaeological reconnaissance 1978. The preliminary report on the third phase of the comprehensive archaeological survey program the coastal province. Atlal, the Journal of Saudi Arabian Archaeology 3: 9-42.

Zarins, J., Whalen, N., Ibrahim, M., Abd al Jawad Mursi, Khan, M., 1980. The Comprehensive Archaeological Survey program. Preliminary report on the Central and Southwestern provinces. Atlal, the Journal of Saudi Arabian Archaeology 4: 9-36.

Zarins J., Al-Jawad Murad, A., Al-Yish, K.S., 1981. The Comprehensive Archaeological Survey Program, a. The second preliminary report on the southwestern province. Atlal, the Journal of Saudi Arabian Archaeology 5: 9-42.

\section{Endnotes}

${ }^{1}$ Other comparable barriers are the Sahara desert, which would have constrained movement between sub-Saharan Africa and North Africa, and the arc of the Taurus-Zagros mountains and the Iranian plateau, providing a series of physical or climatic barriers extending from Anatolia to the Indian subcontinent.

${ }^{2}$ It would be fair to say that there is also no decisive evidence to refute the possibility of such movements.

${ }^{3}$ Strictly speaking this is a strike-slip fault structure resulting in the creation of long and relatively narrow valleys, but with many of the same tectonic and topographic features as the African Rift, including lake basins, fault barriers and lava fields.

${ }^{4}$ This site is referred to as Al Qamah in Bailey et al. 2007a to distinguish it from a Holocene shell midden to the north of the town of Al Birk. It is one of a number of sites in the area and is in fact closer to Al Birk.

${ }^{5}$ Charles Darwin, of course, famously observed that 'To knock a limpet from the rocks does not require even cunning, that lowest power of the mind' (Darwin 1839, p. 235-6). 